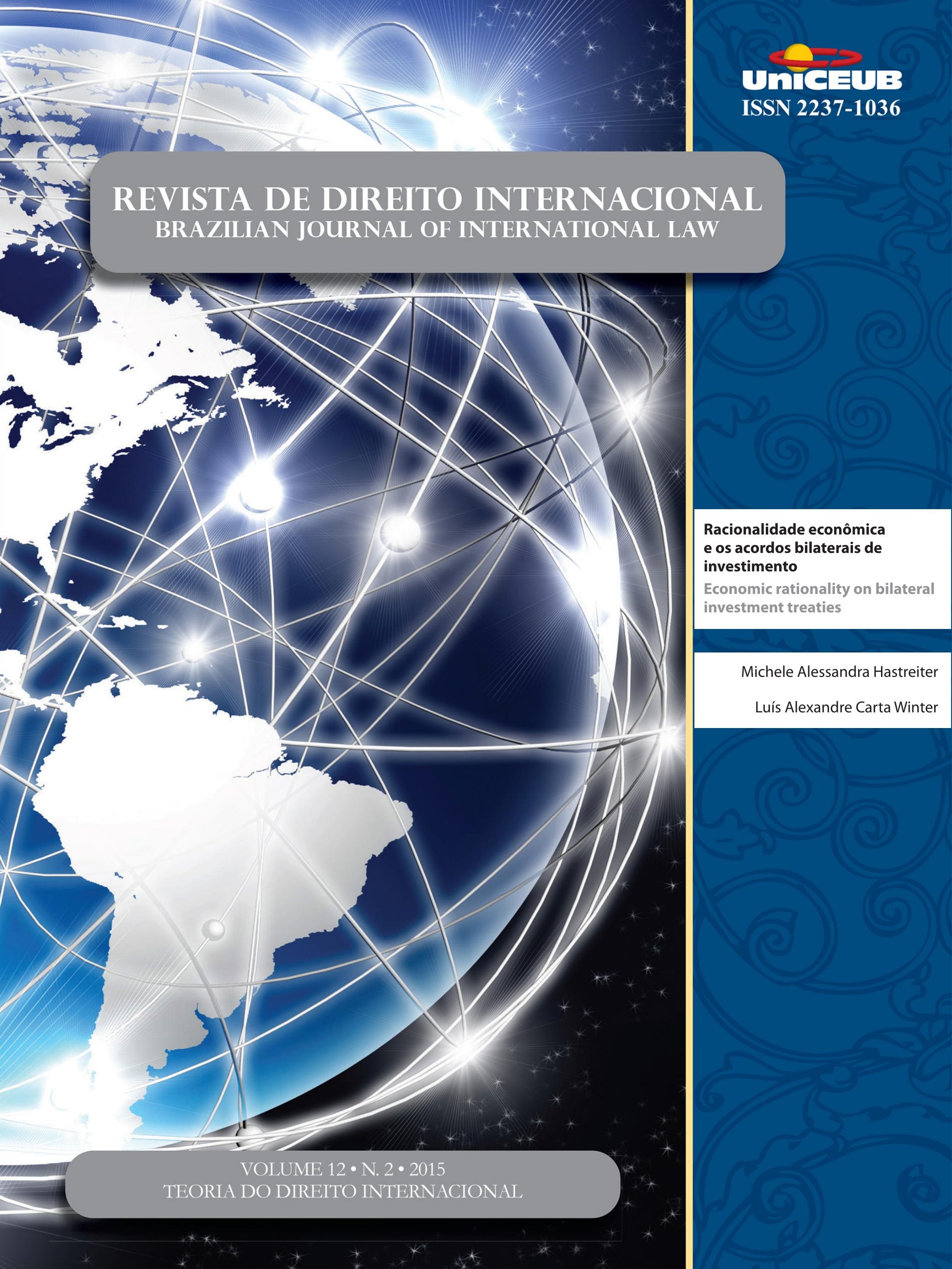




\section{Sumário}

CrôNiCAS DA ATUALIDADE do DiREITo INTERnACIONAL ..................................................... 2 Sarah Dayanna Lacerda Martins Lima, Carina Costa de Oliveira e Erika Braga

CrôniCas do Direito InternaCional dos InVESTIMENTOS ..............................................12 Nitish Monebhurrun

Por que voltar a Kelsen, o jurista do século XX ? 16 Inocêncio Mártires Coelho

O Princípio da Efetividade como conteúdo da norma fundamental (GrundNorm) DE KELSEN

Carlos Alberto Simões de Tomaz e Renata Mantovani de Lima

A JURIDIFICAÇÃo DE CONFLITOS POLÍTICOS NO DIREITO INTERNACIONAL PÚBLICO CONTEMPORÂ-

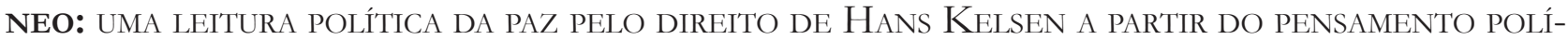
TICO De Claude Lefort

Arthur Roberto Capella Giannattasio

O SINCRETISMO TEÓRICO NA APROPRIAÇÃO DAS TEORIAS MONISTA E DUALISTA E SUA QUESTIONÁVEL UTILIDADE COMO CRITÉRIO PARA A CLASSIFICAÇÃO DO MODELO BRASILEIRO DE INCORPORA-

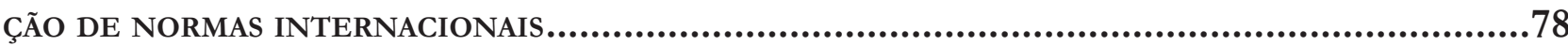
Breno Baía Magalhães

Direito Global em Pedaços: Fragmentação, Regimes e Pluralismo .98 Salem Hikmat Nasser

Por uma TeOria JURÍdica da INTEGRaÇão REgIONAL: A INTER-RELAÇÃO DiREITO INTERNO, DiREITO INTERNACIONAL PÚBLICO E DIREITO DA INTEGRAÇÃO Jamile Bergamaschine Mata Diz e Augusto Jaeger Júnior

A teOria DA INTERCONSTITUCIONALIDADE: UMA ANÁlISE COM BASE NA AMÉRICA LATINA...........160 Daniela Menengoti Ribeiro e Malu Romancini 
O DIÁLOGO HERMENÊUTICO E A PERGUNTA ADEQUADA À APLICAÇÃo DOS TRATADOS INTERNACIONAIS DE DIREITOS HUMANOS NO BRASIL: CAMINHOS PARA O PROCESSO DE INTERNACIONALIZAÇÃO

DA CONSTITUIÇÃO...................................................................................... 176

Rafael Fonseca Ferreira e Celine Barreto Anadon

O DIREITO COMPARADO NO STF: INTERNACIONALIZAÇÃO DA JURISDIÇÃO CONSTITUCIONAL BRASILEIRA

Carlos Bastide Horbach

THE PHILOSOPHY OF INTERNATIONAL LAW IN CONTEMPORARY SCHOLARSHIP: OVERCOMING NE-

GLIGENCE THROUGH THE GLOBAL EXPANSION OF HUMAN RIGHTS

Fabrício Bertini Pasquot Polido, Lucas Costa dos Anjos e Vinícius Machado Calixto

OpORTUNIDADES E DESAFIOS DAS TWAIL NO CONTEXTO LATINO-AMERICANO A PARTIR DE PERSPECTIVAS DOS POVOS INDÍGENAS AO DIREITO INTERNACIONAL

Fernanda Cristina de Oliveira Franco

Por Que uma ANÁlise ECONÔMICA Do DIREITO INTERNACIONAL PÚBLICO? DESAFIOS E PERSPECTIVAS DO MÉTODO NO BRASII

Gustavo Ferreira Ribeiro e Jose Guilherme Moreno Caiado

ANÁliSE ECONÔMICA do DIREITO INTERNACIONAL .263 Michele Alessandra Hastreiter e Luís Alexandre Carta Winter

RACIONALIDADE ECONÔMICA E OS ACORDOS BILATERAIS DE INVESTIMENTO 284 Michele Alessandra Hastreiter e Luís Alexandre Carta Winter

LOOKING FOR A BRICS PERSPECTIVE ON INTERNATIONAL LAW .304 Gabriel Webber Ziero

A INFLUÊNCIA DO DIREITO DESPORTIVO TRANSNACIONAL NO ORDENAMENTO JURÍDICO BRASILEIRO: DA REPRODUÇÃO DE NORMAS À APLICAÇÃO DIRETA PELA JURISDIÇÃO ESTATAL.......................3324 Tiago Silveira de Faria

CONVENCIONALIZAÇÃo DO DIREITO CIVIL: A APLICAÇÃo DOS TRATADOS E CONVENÇÕES INTERNACIONAIS NO ÂMBITO DAS RELAÇÕES PRIVADAS . 
NATIONAL JUdGES AND COURTS AS INSTITUTIONS FOR GLOBAL ECONOMIC GOVERNANCE 356

Juízes e tribunais nacionais como instituições para a governança global 356 Camilla Capucio

Is Trade Governance Changing? 371 Alberto do Amaral Júnior

OS FUNDOS ABUTRES: MEROS PARTICIPANTES DO CENÁRIO INTERNACIONAL OU SUJEITOS PERANTE O DIREITO INTERNACIONAL? 384

Guilherme Berger Schmitt

SHAREHOLDER AGREEMENTS IN PUBLICLY TRADED COMPANIES: A COMPARISON BETWEEN THE

U.S. AND BRAZIL. 402 Helena Masullo

REgulaÇÃo DO INVESTIMENTO ESTRANGEIRO DIRETO NO BRASIL: DA RESISTÊNCIA AOS TRATADOS BILATERAIS DE INVESTIMENTO À EMERGÊNCIA DE UM NOVO MODELO REGULATÓRIO 421 Fabio Morosini e Ely Caetano Xavier Júnior

DA QUALIFICAÇÃo JURÍDiCA dAS Distintas FORMAS DE PRESTAÇão TECNOLÓGICA: BREVE ANÁLISE DO MARCO REGULATÓRIO INTERNACIONAL

Daniel Amin Ferraz

REDEFINING TERRORISM: THE DANGER OF MISUNDERSTANDING THE MODERN WORLD'S GRAVEST THREAT

Jennifer Breedon

As EXECUÇões SELETIVAS E A RESPONSABILIZAÇÃo DE AGENTES TERRORISTAS 485 Alexandre Guerreiro

INTERNATIONAL CRIMINALS AND THEIR VIRTUAL CURRENCIES: THE NEED FOR AN INTERNATIONAL EFFORT IN REGULATING VIRTUAL CURRENCIES AND COMBATING CYBER CRIME Joy Marie Virga

Criminalidad transnacional organizada en el Ámbito del MERCOSUR: ¿Hacia un Derecho Penal Regional?. .528 Nicolás Santiago Cordini e Mariano Javier Hoet 
RUMO À INTERNACIONALIZAÇÃo DA PROTEÇÃO PENAL DO MEIO AMBIENTE: DOS ECOCRIMES AO ECOCÍDIO

Kathia Martin-Chenut, Laurent Neyret e Camila Perruso

Engaging the U.N. Guiding Principles on Business and Human Rights: the inter-AMERICAN COMMISSION ON HUMAN RIGHTS \& THE EXTRACTIVE SECTOR 571 Cindy S. Woods

O DIREITO HUMANO À COMUNICAÇÃo PRÉVIA E PORMENORIZADA DAS ACUSAÇÕES NOS PROCESSOS administrativos: O desprezo do Superior Tribunal de Justiça ao Pacto de San José da Costa Rica e À Corte Interamericana de Direitos Humanos .590

Daniel Wunder Hachem e Eloi Pethechust

A responsabilidade internacional do Brasil em FaCe do CONTRole de ConVENCionaliDADE EM SEDE DE DIREITOS HUMANOS: CONFLITO DE INTERPRETAÇÃO ENTRE A JURISDIÇÃO DA Corte Interamericana de Direitos Humanos e o Supremo Tribunal Federal quanto a LEI DE ANISTIA 612

Carla Ribeiro Volpini Silva e Bruno Wanderley Junior

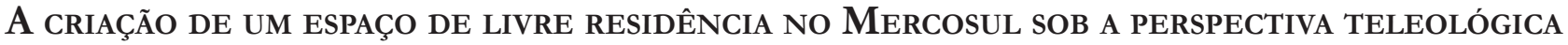
DA INTEGRAÇÃo REGIONAL: ASPECTOS NORMATIVOS E SOCIAIS DOS ACORDOS DE RESIDÊNCIA ....... 631

Aline Beltrame de Moura

A funcionalização como tendênCia evolutiva do Direito Internacional e sua conTRIBUIÇÃO AO REGIME LEGAL DO BANCO DE DADOS DE IDENTIFICAÇÃO DE PERFIL GENÉTICO NO BRASIL

Antonio Henrique Graciano Suxberger

O DIREITO INTERNACIONAL E A PROTEÇÃO DOS DIREITOS DE CRIANÇAS E DE ADOLESCENTES EM CONFLITO COM A LEI EM MOÇAMBIQUE

Bernardo Fernando Sicoche

ObTenÇão de PRovas no EXTERIOR: PARA ALÉM dA LEX FORI E LEX DiLigENTIAE. .685 André De Carvalho Ramos 
A Slight Revenge and a Growing Hope for Mauritius and the Chagossians: The UNClos Arbitral Tribunal's Award of 18 March 2015 on Chagos Marine Protected Area (Mauritius v. United Kingdom)

Géraldine Giraudeau

ANÁLISE DA RESPONSABILIDADE INTERNACIONAL DA UCRÂNIA POR VIOLAÇÃo DOS DIREITOS HUmanos na QUeda do voo da Malaysia Airlines (MH17). .728

Daniela Copetti Cravo

NatureZa JURÍdica do DESENVOLVIMENTO SUSTENTÁVEL No DIREITO INTERNACIONAL ........739 Pedro Ivo Diniz

A INFLUÊNCIA Da SOFT LAW NA FORMaÇão do DiREITo AMBIENTAL .767 Leonardo da Rocha de Souza e Margareth Anne Leister

As COMPLICADAS INTER-RELAÇÕES ENTRE OS SISTEMAS INTERNOS E INTERNACIONAIS DE PROTEÇãO DO DIREITO AO MEIO AMBIENTE SADIO. 785 José Adércio Leite Sampaio e Beatriz Souza Costa 


\title{
Racionalidade econômica e os acordos bilaterais de investimento*
}

\section{Economic rationality on bilateral investment treaties}

\author{
Michele Alessandra Hastreiter** \\ Luís Alexandre Carta Winter***
}

\section{Resumo}

Este artigo analisa a decisão dos países de celebrar acordos internacionais de investimento sob o prisma da racionalidade econômica, com o objetivo de mensurar a adequação da postura brasileira sobre o tema. Por meio do método dedutivo de abordagem e utilizando-se do ferramental teórico da Análise Econômica do Direito (AED) e de referencial bibliográfico, o estudo conclui que a decisão racional dos estados de celebrarem acordos de investimento não pode mais ser mensurada sob um paradigma dicotômico, que opõe, de um lado, países desenvolvidos e exportadores de capital e, do outro, países em desenvolvimento e receptores do investimento externo. Em um novo cenário no qual a definição de país investidor e país receptor de investimento torna-se mais nebulosa, a perspectiva racional autointeressada pode demandar acordos de caráter mais equilibrados do que aqueles difundidos na década de 1990, sendo compatível, portanto, com a tendência observada de reformulação das principais disposições desses acordos - caminho este que parece estar sendo trilhado pelo Brasil ao engajar-se recentemente em negociações sobre o tema. Sustenta-se, assim, a possibilidade do Brasil assumir a liderança no processo de reformulação das normas sobre a matéria no cenário internacional.

* Recebido em 17/09/2015

Aprovado em 07/12/2015

** Mestre em Direito pela Pontifícia Universidade Católica do Paraná. Professora de Direito Internacional Público e Privado no Centro Universitário Curitiba (UNICURITIBA). Membro da Comissão de Direito Econômico da Ordem dos Advogados do Brasil - Seção do Paraná. Membro do Núcleo de Estudos Avançados em Direito Internacional (NEADI) da PUCPR. Advogada e Administradora Internacional de Negócios, graduada pela Pontifícia Universidade Católica do Paraná e pela Universidade Federal do Paraná, respectivamente. Email: michele.hastreiter@gmail.com.

*** Doutor pela USP. Professor do PPGD da PUCPR. Professor titular da PUCPR; UNICURITIBA e da FAMEC. Coordenador do Núcleo de Estudos Avançados em Direito Internacional (NEADI - PUCPR). E-mail: luisalexandrecartawinter@yahoo.com.br.
Palavras-chave: Acordos bilaterais de investimento. Racionalidade econômica. Análise econômica do direito. Direito internacional do investimento estrangeiro. Teoria da escolha racional.

\section{Abstract}

This article examines the decision made by countries to conclude bilateral investment treaties through the prism of economic rationality, in order to measure the adequacy of the Brazilian position on the subject. Through deductive approach and using the theoretical tools of Economic Analysis of Law and bibliographic research, the study concludes that the rational decision of the states to conclude investment agreements can no longer be measured in a dichotomous paradigm, opposing on the one hand, developed countries as capital exporters and on the other hand, developing countries as recipients of foreign investment. In this new scenario, the rational and self-interested perspective can demand a more balanced agreement than those 
broadcasted in the 1990s and is compatible, therefore, with the trend to recast the main provisions of these agreements - a path that seems to be the one that Brazil chose while negotiating recently on the subject.

Keywords: Bilateral investment treaties. Economic rationality. Economic analysis of law. International law of foreign investment. Rational choice theory.

\section{INTRODUÇÃO}

O presente estudo tem como objetivo analisar, por meio do pressuposto da racionalidade econômica, as razões pelas quais os países engajam-se na negociação e assinatura de acordos bilaterais de investimentos estrangeiros - um dos mais polêmicos temas de Direito Internacional Econômico na atualidade.

Trata-se de uma sistemática de regulação amplamente difundida nas últimas décadas. Embora o primeiro desses acordo de proteção e promoção de investimentos tenha sido celebrado entre Alemanha e Paquistão, em 1959¹ foi na década de 1990 - quando o mainstream econômico defendia que o desenvolvimento seria o resultado de um regime que permitisse que os atores de mercado transacionassem livremente, nacional e internacionalmente - que esses acordos encontraram o cenário ideal para sua disseminação. Em 1990, eram 446 os acordos bilaterais existentes no mundo ${ }^{2}$. Ao final de 2013, havia 3.236 acordos sobre a temática em vigor, sendo 2.902 acordos bilaterais de proteção e outros 334 acordos de outras naturezas, dentre os quais os acordos regionais ou de livre comércio que também abordam a matéria $^{3 .}$

Embora não sigam um padrão único, esses acordos possuem regras comuns, que representam a essência do

1 GERMANY. Treaty between the Federal Republic of Germany and Pakistan for the prootion and protection of investments. Available in: <http:/ / investmentpolicyhub.unctad.org/Download/TreatyFile/1387>. Access: Out. 29, 2014

2 SCANDIUCCI FILHO, José Gilberto. O Brasil e os acordos bilaterais de investimentos. In: AMARAL JÚNIOR, Alberto do; SANCHEZ, Michelle Ratton. Regulamentação internacional dos investimentos: algumas lições para o Brasil. São Paulo: Aduaneiras, 2007. p. 271-302. p. 279.

3 UNITED NATIONS CONFERENCE ON TRADE AND DEVELOPMENT. World Investment Report 2014: investing in the SDGs: an action plan. New York: United Nations, 2014. Available in: <http://unctad.org/en/publicationslibrary/wir2014_en.pdf>. Access: Sept. 8, 2014
Direito Internacional do Investimento contemporâneo ${ }^{4}$ Além disso, boa parte deles também estabelece um consentimento arbitral genérico por parte dos países signatários, que podem ser demandados por quaisquer empresas provenientes dos países com quem possuem acordos bilaterais perante uma corte arbitral, para solucionar as controvérsias oriundas desses acordos.

A intensa celebração desses acordos a partir da década de 1990 se aliava à crença na cartilha para o desenvolvimento econômico propugnada pelo Consenso de Washington e foi um dos sinais da vitória do capitalismo ocidental sobre as economias planificadas socialistas e comunistas. Por isso, eles se consagraram, em suma, como instrumentos voltados à proteção dos direitos de propriedade dos investidores. Na prática, porém, o sistema de regulação gerou efeitos inesperados em razão do excesso de proteção que concedeu aos investidores sem qualquer exigência de contrapartida. Há indícios de que, ao tentar equilibrar a balança compensando a fragilidade do investidor, os acordos tenham, na realidade, feito com que a balança pendesse para o outro lado, gerando, assim, uma assimetria em prol do capital internacional. Além disto, como os acordos quase sempre eram celebrados entre países desenvolvidos e países em desenvolvimento, o fluxo de investimentos que cobriam era unilateral - o que gerava um desequilíbrio nas obrigações assumidas pelos países signatários ${ }^{5}$. Isso fez com que os acordos se tornassem preocupações para governos, ONGs e acadêmicos.

O que se nota, porém, é que, a despeito das dificuldades para aprovação de instrumentos multilaterais so-

4 As regras sobre Expropriação (direta e indireta), o Tratamento Nacional, o Tratamento da Nação Mais Favorecida e o Tratamento Justo e Equitativo, por exemplo, estão presentes na quase totalidade dos acordos. Sobre o conteúdo típico dos acordos, sugere-se a leitura de: MONEBHURRUN, Nitish. Crônicas do direito internacional dos investimentos. Revista de Direito Internacional, Brasília, v. 11, n. 1, p. 10-18, 2014. p. 10-18; ARENHART, Fernando Santos. Investimento estrangeiro: o padrão de tratamento justo e equitativo e o papel da boa fé. Revista de Direito Internacional, Brasília, v. 10, n. 1, p. 154-169, 2013. p. 154-169; POSTIGA, Andréa Rocha. A emergência do direito administrativo global como ferramenta de regulação transnacional do investimento estrangeiro direto. Revista de Direito Internacional. Brasília, v. 10, n. 1, p. 171-193, 2013. p. 171-193; DOLZER, Rudolf; SCHREUER, Christoph. Principles of international investment law. Oxford: Oxford University, 2012; SORNARAJAH, M. The international law on foreign investment. Cambridge: Cambridge University, 2010.

5 Acerca desse desequilíbrio, ver: MONEBHURRUN, Nitish. Essay on unequal treaties and modernity throgh the example of bilateral investment treaties. Revista de Direito Internacional, Brasilia, v. 11, n. 1, p. 202-214, 2014. 
bre a matéria, os acordos bilaterais de investimento têm sido prática corriqueira nas negociações internacionais contemporâneas. Ainda que haja uma crescente preocupação com a abrangência e excessiva proteção concedida aos investidores em algumas de suas cláusulas, fato é que os acordos são extremamente disseminados e são uma ferramenta institucional significativa para regulação da economia globalizada. Diante desse cenário, mostra-se importante compreender por que os países assinam esses acordos.

Essa análise reveste-se de especial pertinência em um momento em que o Brasil revisa sua postura acerca da matéria. Seguindo a tendência mundial, o Brasil assinou quatorze acordos dessa natureza na década de 1990, sem, contudo, ratificá-los. Desde então, o país tem sido uma notória exceção no sistema de regulação internacional sobre a temática, já que não se encontra vinculado a nenhum acordo. Apesar disso, é uma das economias que mais atrai o capital internacional. Não obstante, em 2013, o país anunciou o início de negociações bilaterais com países africanos e latino-americanos. Em 30 de março de 2015, anunciou a celebração de Acordo de Cooperação e Facilitação de Investimentos com Moçambique. Em 01 de abril de 2015, o país assinou um acordo semelhante com a Angola. Em 28 de maio de 2015, o mesmo acordo foi assinado com o México. Em 23 de novembro de 2015, o país assinou acordo com o Chile. Além desses países, o Brasil também negocia a assinatura de tais acordos com a África do Sul, Argélia, Colômbia, Malaui, Marrocos, Peru e Tunísia ${ }^{6}$.

Embora esses acordos assinados ainda estejam pendentes de ratificação, a recente mudança de perspectiva sobre a temática reacende os debates sobre o tema no país. Compreender o que está por trás da decisão de engajar-se em negociações de acordos bilaterais de investimento mostra-se útil para avaliar a adequação da postura brasileira. Assim, o presente artigo, com a ajuda dos postulados teóricos da Análise Econômica do Direito, busca estabelecer o que norteia a decisão racional dos países signatários desses acordos, tanto dos países

6 Estas informações encontram-se disponíveis no site do Itamaraty. BRASIL. Ministério das Relações Exteriores. Acordo BrasilMéxico de Cooperação e Facilitação de Investimentos: Cidade do México, 26 de maio de 2015. Brasília: MRE, 27 maio 2015. Disponível em: $<$ http://www.itamaraty.gov.br/index.php?option=com_conten $\mathrm{t} \&$ view $=$ article $\& i d=9890$ :acordo-brasil - mexico-de-cooperacaoe-facilitacao-de-investimentos-cidade-do-mexico-26-de-maio-de$2015 \&$ catid $=42 \&$ lang $=$ pt-BR\&Itemid $=280>$. Acesso em: 03 fev. 2016.

desenvolvidos, como os em desenvolvimento, para, ao fim, enfocar a mudança de racionalidade exigida em um contexto no qual as diferenças entre países investidores e receptores de investimento tornam-se mais nebulosas. Para isso, sugere-se que há uma nova racionalidade possível, pautada na perspectiva do "véu da ignorância" de John Rawls, já que a teoria estabelece como agentes racionais podem concordar com princípios equilibrados de justiça distributiva quando desconhecem sua posição perante os demais. Sustenta-se, assim, que há uma tendência dos acordos internacionais de investimento se tornarem mais equilibrados na medida em que as posições dos países como investidores ou receptores de capital não é mais tão clara. O modelo de acordo brasileiro corrobora essa perspectiva.

\section{A racionalidade EConômica dos países SIGNATÁRIOS DE ACORDOS BILATERAIS DE INVESTI- MENTO}

Um dos postulados do pensamento econômico é o da racionalidade econômica. A ideia de racionalidade econômica parte da premissa de que os desejos dos seres humanos são ilimitados, mas o mundo possui escassos recursos para realizá-los. Assim, a escassez de recursos impõe aos agentes que escolham, entre alternativas possíveis e excludentes, onde aplicar esses recursos. Para escolher entre as opções possíveis, os indivíduos ponderam custos e benefícios de cada curso de ação - decidindo pela opção que atende melhor os seus interesses. Nesse contexto, a conduta dos agentes econômicos é racional maximizadora - isto é, os indivíduos tendem a agir de forma a maximizar suas utilidades, visando extrair o máximo de satisfação possível para si com o menor custo.

A aplicação do pressuposto da racionalidade econômica ao Direito é um dos postulados da Análise Econômica do Direito, método que consiste na aplicação do:

\begin{abstract}
instrumental analítico e empírico da economia, em especial da microeconomia e da economia do bemestar social, para se tentar compreender, explicar e prever as implicações fáticas do ordenamento jurídico, bem como da lógica (racionalidade) do próprio ordenamento. ${ }^{7}$
\end{abstract}

7 GICO JR., Ivo. Metodologia e epistemologia da análise econômica do direito. Economic Analysis of Law Review, v. 1, n. 1, p. 7-33, Jan./ June 2010. p. 18. Available in: <http://portalrevistas.ucb.br/index. 
Trata-se de uma perspectiva especialmente interessante ao Direito Internacional, ramo do Direito que se desenvolve em um ambiente de anarquia, na ausência de um Estado hobbesiano para forçar uma cooperação entre as partes.

Aplicando a perspectiva da escolha racional aos acordos internacionais de investimento, pode-se dizer que os países assinarão acordos de investimento quando perceberem que estarão - de alguma forma - em uma situação melhor fazendo parte dessa estrutura de cooperação do que ao se recusarem a participar. Em verdade, precisamente, no tocante aos acordos de investimento, Robert Scott e Paul Stephan ${ }^{8}$ destacam que essa cooperação movida pela racionalidade tornou-se de tal forma elevada que o corpo de normas por eles originado é hoje um dos exemplos mais evidentes do fortalecimento do Direito Internacional, que, paulatinamente, está construindo o seu próprio "Leviatã".

Considerando que os acordos internacionais de investimento são tradicionalmente celebrados entre países desenvolvidos e em desenvolvimento - e que esses países têm objetivos diferentes nas negociações de investimento - compreender o porquê dos Estados estarem aderindo a esse sistema de proteção do capital internacional exige que se vislumbre as perspectivas desses países separadamente.

\subsection{A perspectiva dos países desenvolvidos}

O relacionamento entre países desenvolvidos e suas empresas domésticas remete-nos a períodos longínquos

php/EALR/article/view/1460/1110>. Access: Out. 21, 2014. 8 SCOTT, Robert E.; STEPHAN, Paul B. The limits of Leviathan: contract theory and the enforcement of international law. Cambridge: Cambridge University, 2006. p. 3.

9 Nesse sentido, os autores afirmam que "o Direito Internacional era soft, no sentido de que não existia um Leviatã hobbesiano para sancionar o seu descumprimento. A nova abordagem, de modo contrário, autoriza a exequibilidade privada, emprega tribunais independentes e cortes para forçar o seu cumprimento e concede poderes a esses tribunais na mesma medida em que as cortes domésticas possuem para fazer valer suas decisões. O Direito Internacional tornouse hard, com o seu próprio Leviatã". No original: "International law was soft, in the sense that there existed no Hobbesian Leviathan to sanction default. The new approach, in contrast, allow private enforcement, employs independent tribunals and courts to do the enforcing, and empowers those tribunals and courts to wield the same array of tools that domestic courts traditionally use to compel compliance with their decisions. International law has become hard law, with its own Leviathan." (SCOTT, Robert E.; STEPHAN, Paul B. The limits of Leviathan: contract theory and the enforcement of international law. Cambridge: Cambridge University, 2006. p. 3.) na história. Há quem afirme que o alinhamento entre investidor e Estado foi crucial para os objetivos expansionistas do período colonial, o que se mostra, particularmente, evidente no relacionamento de países europeus com as Companhias das Índias Orientais ${ }^{10}$. Atualmente, porém, as empresas não mais representam uma longa manus dos Estados para tratar de questões comerciais, como faziam outrora. Em verdade, as corporações de hoje transformaram-se em grandes centros de poder, tendo, muitas vezes, uma "política externa própria"11. Apesar disto, os Estados continuam defendendo os interesses de suas empresas externamente.

A decisão do Estado nacional de intervir em favor de seus investidores, não apenas após a ocorrência de uma violação concreta, mas de forma proativa pela negociação de acordos internacionais - despendendo para isto, tempo e outros recursos escassos - pode ter múltiplas explicações. Uma das primeiras razões pelas quais os Estados podem decidir apoiar suas empresas internacionalmente é geopolítica: segundo Celso Albuquerque de $\mathrm{Mello}^{12}$, a presença de empresas nacionais no exterior aumenta o prestígio político do Estado, razão pela qual as empresas transnacionais contam com o apoio diplomático de seus Estados nacionais.

Além disso, uma das consequências inexoráveis do acirramento do processo de globalização são as externalidades econômicas promovidas pelo cada vez mais livre fluxo de bens, pessoas, serviços e capitais. Externalidades são os efeitos que a conduta de determinados agentes produz sobre terceiros ${ }^{13}$. Quando um Estado receptor expropria um investidor estrangeiro, ele está diminuindo a quantidade de recursos disponíveis no Estado doméstico da empresa, na medida em que o investimento realizado baseava-se na expectativa legítima de poder repatriar os lucros obtidos ${ }^{14}$.

10 MILES, Kate. The origins of international investment law. Cambridge: Cambridge University, 2013. p. 45-47.

11 MELLO, Celso Albuquerque de. Direito internacional econômico. Rio de Janeiro: Renovar, 1993. p. 108-109.

12 MELLO, Celso Albuquerque de. Direito internacional econômico. Rio de Janeiro: Renovar, 1993. p. 109.

13 Externalidades negativas acontecem quando uma pessoa se dedica a uma atividade que trás benefícios privados, mas que causa prejuízos a outros (por exemplo, a poluição de uma fábrica), ao passo que as externalidades positivas, surgem quando uma pessoa desempenha uma ação que beneficia os outros. (POSNER, Eric A.; SYKES, Alan O. economic foundations of international law. Cambridge: Harvard University, 2013. p. 19).

14 É por isso que a presunção de que o ingresso de capital do exterior é importante pelo impacto positivo que produz ao balanço de pagamentos merece ressalvas. O estudo de S. M. Cunningham, por exemplo, indica que os montantes repatriados podem ser até duas vezes maiores 
Além disso, o enfraquecimento da empresa expropriada também pode afetar o desempenho da matriz no Estado doméstico, comprometendo sua performance econômica. Esta é uma externalidade negativa que os Estados domésticos podem buscar endereçar através dos instrumentos de proteção dos investidores. Dessa forma, manter suas empresas fortes internacionalmente pode ser importante para o desenvolvimento interno do país de origem da empresa.

É possível, porém, que a decisão de suportar as empresas internacionalmente possa ter embasamentos que nem sempre resistem a um juízo arrazoado de razão pública ${ }^{15}$. Como bem sustentou Douglas North ${ }^{16}$, muitas vezes é a parte com maior poder de barganha que vê seus interesses prevaleceram na formação das instituições, ao contrário da maximização do bem-estar coletivo - o que gera uma economia ineficiente. A teoria de Mancur Olson ${ }^{17}$ sobre a escolha pública também contribui para esta compreensão, na medida em que o autor esclarece o papel dos diferentes grupos de interesses na formação das decisões governamentais: embora existam grandes grupos de interesse na sociedade que permanecem inertes e, portanto, incapazes de

do que o aporte inicial de capital, o que indica que embora a repercussão inicial possa ser positiva, o capital estrangeiro pode contribuir para tornar o balanço de pagamentos do país receptor deficitário - e o do emissor de investimentos superavitário - no longo prazo. Nesse sentido, ver: CUNNINGHAM, S. M. Multinationals and restructuring in Latin America. In: DIXON, Chris; DRAKAKIS-SMITH, David; WATTS, Doug (Ed.). Multinational corporations and the third world. New York: Routledge, 1986. v. 11. p. 39-65.

15 O conceito de razão pública foi expresso por John Rawls, que a considera como uma ideia do que é politicamente razoável, tendo em vista que os indivíduos têm concepções diferentes religiosas, filosóficas e morais, para que um governo democrático possa direcionar suas ações. (RAWLS, John. O direito dos povos. Tradução de Luís Carlos Borges. São Paulo: M. Fontes, 2001. p. 173). Amartya Sen defende, de modo semelhante, a "argumentação racional pública" fundada na ideia de democracia formada com o "governo por meio do debate" (SEN, Amartya. A ideia de justiça. Tradução de Denise Bottmann e Ricardo Doninelli Mendes. São Paulo: Companhia das Letras, 2009. p. 09).

16 NORTH, Douglass C. Economic performance through time. American Economic Review, v. 84, n. 3, p. 359-368, June 1994. p. 360.

$17 \mathrm{O}$ autor afirma que pequenos grupos privilegiados com interesses especiais têm poder desproporcional quando comparado a grandes grupos. Como exemplo, o ator cita que um grupo pequeno composto por industriais oligopolistas desejando uma isenção tributária pode por vezes ver o seu objetivo ser atendido mesmo quando a maior parte da população perde como um resultado disto. Os grupos menores e privilegiados podem, frequentemente, vencer grupos grandes - ao contrário do que deveria acontecer em uma democracia porque geralmente são mais organizados e ativos do que os grupos grandes, como a sociedade civil. (Neste sentido, ver em: OLSON, Mancur. The logic of collective action: public goods and the theory of groups. Cambridge: Harvard University, 1965. p. 127-128). pressionar o governo para a obtenção de políticas que lhe são favoráveis, outros, por diversos motivos, ainda que menores em número e com interesses que propiciam menores ganhos globais, conseguem se organizar melhor e encontram meios para influenciar mais fortemente as decisões governamentais. É necessário, nesse sentido, destacar o enorme poder de barganha de certos investidores internacionais, que podem fazer valer suas pressões inclusive mediante uma influência direta sobre os representantes dos Estados, pela corrupção e pelo suborno, ou por meio de contribuições empresariais às campanhas políticas com exigências explícitas ou veladas de contrapartida ${ }^{18}$.

De toda sorte, como se viu da análise do conteúdo desses acordos, fato é que eles estabelecem obrigações apenas para os Estados receptores do investimento, de tal forma que uma vez que o Estado doméstico tenha firmado tal compromisso, ele se exime de maiores preocupações com o investimento. Tais acordos contam, em sua maioria, com mecanismos de solução de controvérsia que concedem aos investidores o poder de acionar o Estado receptor diretamente, reduzindo as preocupações do Estado doméstico inclusive quando há uma violação concreta. Percebe-se, assim, que após incorrer nos custos transacionais para a negociação e celebração dos acordos, os Estados investidores apenas se beneficiam da assinatura de tais instrumentos, não assumindo nenhuma obrigação adicional - especialmente nos acordos firmados sob os moldes tradicionais e entre um país claramente investidor e outro exclusivamente receptor de capital.

Assim, nas relações bilaterais em que os países desenvolvidos são essencialmente emissores de investimentos, não é difícil explicar as razões pelas quais celebram os acordos de investimento. Explicar porque os países em desenvolvimento aderem a tais compromissos - nos quais, se não possuem investimentos externos a proteger, são os únicos detentores de obrigações mostra-se, portanto, uma questão mais complexa.

\subsection{A perspectiva dos países em desenvolvi- mento}

Os países em desenvolvimento sempre se opuseram aos padrões de tratamento a investidores estrangeiros defendidos pelos países desenvolvidos. Essa oposição

18 STIGLITZ, Joseph E. Globalização: como dar certo. São Paulo: Companhia das Letras, 2007. p. 308. 
foi, inclusive, um dos temas centrais do movimento conhecido como Nova Ordem Econômica Internacional (NOEI), que buscava, na Assembleia Geral das Nações Unidas, rever padrões de Direito Internacional Consuetudinário considerados contrários aos interesses dos novos países independentes ${ }^{19}$. Essa oposição também ficou evidente nas tentativas de negociação multilateral sobre o tema. Por isso, a disseminação dos acordos bilaterais de investimento entre países em desenvolvimento e desenvolvidos pode parecer difícil de explicar.

Andrew Guzman ${ }^{20}$ buscou explicar a popularidade dos acordos bilaterais de investimento a partir, exatamente, dessa perspectiva. $\mathrm{O}$ autor sustenta, então, que o comportamento dos países em desenvolvimento pode ser explicado pela constatação da existência de uma "inconsistência dinâmica", a qual pode ser definida como:

\begin{abstract}
a situação na qual uma decisão política futura, que faz parte de um plano ideal formulado em data inicial, não é mais ideal do ponto de vista de uma data posterior, ainda que nenhuma informação nova tenha aparecido no mesmo período" 21 .
\end{abstract}

Eric Posner e Alan Sykes ${ }^{22}$ também conceituam essa inconsistência temporal, afirmando que, em um determinado momento, os governos identificam que um determinado curso de ação é mais favorável, mas as circunstâncias podem mudar e essa opção pode não ser mantida em um novo contexto.

No que diz respeito aos investimentos estrangeiros, tem-se que é importante que o Estado adote medidas para parecer atrativo aos investidores internacionais. No entanto, após a realização do investimento, o Estado não precisa mais preocupar-se em manter as condições com as quais se comprometeu para atraí-lo, sendo suficiente que não as piore tanto a ponto de não conseguir manter o investimento em seu território. Uma vez que um investimento tenha sido realizado, o desinvestimen-

19 COSTA, José Augusto Fontoura. Direito internacional do investimento estrangeiro. Curitiba: Juruá, 2010. p. 169.

20 GUZMAN, Andrew. Why LDCs sign treaties that hurt them: explaining the popularity of bilateral investment treaties. Virginia Journal of International Law, v. 38, n. 639, p. 639-688, 1998. Available in: $<$ http://papers.ssrn.com/sol3/papers.cfm?abstract_id=2176003>. Access: Nov. 4, 2014.

21 GUZMAN, Andrew. Why LDCs sign treaties that hurt them: explaining the popularity of bilateral investment treaties. Virginia Journal of International Law, v. 38, n. 639, p. 639-688, 1998. p. 644. Available in: <http://papers.ssrn.com/sol3/papers.cfm?abstract_ id=2176003 > . Access: Nov. 4, 2014.

22 POSNER, Eric A.; SYKES, Alan O. economic foundations of international law. Cambridge: Harvard University, 2013. p. 19. to geralmente não pode ser feito de forma completa: quando os investidores montam uma fábrica, por exemplo, os custos já foram feitos e não podem ser recuperados simplesmente desmontando a operação. Assim, os incentivos necessários para a manutenção do investimento no país são menores do que para sua atração, o que faz com que os Estados sejam tentados a agir de forma oportunista, prometendo um tratamento determinado e mudando o seu comportamento após a realização do investimento.

Porém, os investidores não desconhecem essa inconsistência dinâmica e ela os desestimula a investir e, como o Estado receptor precisa do investimento estrangeiro para suas necessidades de desenvolvimento, ela se torna um problema. Os Estados não conseguem firmar um compromisso crível quanto ao tratamento a ser concedido para o investidor dentro de sua regulação doméstica - já que os investidores temem que o governo possa mudar a lei após a realização do investimento, ou que os tribunais domésticos não apliquem as regras que beneficiam os investidores ${ }^{23}$. Assim, os países em desenvolvimento não conseguem - apenas com sua regulação doméstica - oferecer uma segurança jurídica que estimule os investidores a investir.

Em outras palavras, os governos têm incentivos para explorar o investidor que já realizou investimentos irrecuperáveis (aumentando os impostos, criando exigências regulatórias ou expropriando o investimento), mas essa situação prejudica o governo antes da realização dos investimentos, uma vez que aumenta os riscos percebidos pelos investidores, reduzindo o montante de recursos recebido ${ }^{24}$. Os acordos funcionam, nesse contexto, como um meio de estabelecer um compromisso crível entre o Estado receptor e o Estado doméstico do investimento, garantindo a manutenção das condições do investimento e padrões de tratamento e proteção ao investidor internacional.

Em razão do pacta sunt servanda, uma vez que tenha se comprometido com o padrão de tratamento disposto no acordo, os Estados não podem mais alterar os padrões unilateralmente, dependendo, para isso, do consentimento do outro Estado-parte (o Estado doméstico

23 POSNER, Eric A.; SYKES, Alan O. economic foundations of international law. Cambridge: Harvard University, 2013. p. 279.

24 POSNER, Eric A.; SYKES, Alan O. economic foundations of international law. Cambridge: Harvard University, 2013 p. 279. 
do investidor $)^{25}$. Além disso, uma violação ao acordo representa um ilícito internacional, sujeitando o Estado à responsabilidade internacional e às sanções previstas no acordo. Assim, apesar de estabelecerem onerosos compromissos aos países em desenvolvimento, os acordos seriam um meio de superar as dificuldades que esses países teriam para atrair o capital internacional.

Não obstante, Andrew Guzman ${ }^{26}$ afirma que se nenhum país em desenvolvimento tivesse assinado os acordos bilaterais de investimento, os investidores estrangeiros investiriam a despeito dessa inconsistência dinâmica. Embora reconheça que esta é uma questão que dependeria de confirmação empírica, o autor afirma que se trata de uma suposição razoável, já que os países em desenvolvimento são atrativos para os investidores por razões diferentes da atração exercida por países desenvolvidos (disponibilidade de matéria prima ou mão de obra barata, por exemplo). Assim, um país em desenvolvimento geralmente não é uma opção de investimento alternativa a um país desenvolvido, mas sim a outro país em desenvolvimento. Se os países em desenvolvimento atuassem coletivamente resistindo a esses acordos, o efeito prático não seria uma escassez de recursos para essas economias, mas um aumento do preço pago pelos investidores por investir em tais localidades ${ }^{27}$.

Além disso, como a existência de mecanismos de proteção é, apenas, um dos fatores considerados pelos investidores na decisão sobre onde aplicarem seu capital, se não houvesse países oferecendo a estrutura de proteção dos acordos bilaterais, os investimentos aconteceriam mesmo assim - e os países teriam mais liberdade para gerenciá-los. Guzman compara essa situação a de um cartel: os países em desenvolvimento, mantendo-se unidos e em cooperação, poderiam aumentar o preço dos investimentos realizados em seu

25 DIAS, Bernadete de Figueiredo. A abordagem do Direito ao Desenvolvimento nos Tratados sobre Investimentos. In: AMARAL JÚNIOR, Alberto do (Org.). Direito internacional e desenvolvimento. Barueri: Manole, 2005. p. 253-269. p. 199.

26 GUZMAN, Andrew. Why LDCs sign treaties that hurt them: explaining the popularity of bilateral investment treaties. Virginia Journal of International Law, v. 38, n. 639, p. 639-688, 1998. p. 644. Available in: <http://papers.ssrn.com/sol3/papers.cfm?abstract_ id $=2176003>$. Access: Nov. 4, 2014.

27 GUZMAN, Andrew. Why LDCs sign treaties that hurt them: explaining the popularity of bilateral investment treaties. Virginia Journal of International Law, v. 38, n. 639, p. 639-688, 1998. p. 675. Available in: <http://papers.ssrn.com/sol3/papers.cfm?abstract_ id $=2176003>$. Access: Nov. 4, 2014. território, sujeitando-os a uma interferência maior do Estado receptor ${ }^{28}$. Porém, assim como em um cartel, há incentivos para que um país isoladamente rompa com essa cooperação, visando aumentar os investimentos que recebe ao oferecer uma vantagem comparativa à oferecida pelos demais.

A conduta dos países em desenvolvimento pode ser explicada, nesse contexto, com a ajuda do "Dilema do Prisioneiro", ferramenta desenvolvida dentro do estudo de Teoria dos Jogos para tratar de situações em que os indivíduos procuram seus próprios interesses, sem o auxílio de uma autoridade central para forçar uma cooperação ${ }^{29}$ - tal qual o cenário internacional. A história original do Dilema do Prisioneiro narra a situação de dois suspeitos de um crime que foram presos pela polícia e interrogados separadamente. A polícia não tem provas para condená-los, o que abre a possibilidade para que um deles confesse e, com isso, tenha uma pena mais leve, porém condenando o outro a pena maior. Porém, se ambos confessarem, serão condenados à pena máxima. Se nenhum dos dois confessar, adotando uma estratégia de cooperação, ambos teriam uma pena menor.

De acordo com Andrew Guzman ${ }^{30}$, quando atuavam coletivamente nos foros internacionais - especialmente na Assembleia Geral da ONU -, os países em desenvolvimento cooperavam entre si e, assim, conseguiram reduzir o nível de exigências de proteção do investidor feito pelo Direito Internacional costumeiro, tendo uma liberdade maior para gerenciar os investimentos recebidos e podendo, assim, extrair deles um maior benefício. Não obstante, os países - ao mesmo tempo competiam entre si por investimento, de tal forma que possuíam incentivos para "trair" os demais, assinando acordos bilaterais de investimento que representariam uma vantagem comparativa na atração do capital internacional. Ocorre, porém, que a deserção de um país impulsionou os demais a seguirem no mesmo caminho - e uma vez que os acordos tornaram-se altamente dis-

28 GUZMAN, Andrew. Why LDCs sign treaties that hurt them: explaining the popularity of bilateral investment treaties. Virginia Journal of International Law, v. 38, n. 639, p. 639-688, 1998. p. 675. Available in: <http://papers.ssrn.com/sol3/papers.cfm?abstract_ id $=2176003>$. Access: Nov. 4, 2014.

29 AXELROD, Robert. A evolução da cooperação. São Paulo: Leopardo, 2010. p. 6.

30 GUZMAN, Andrew. Why LDCs sign treaties that hurt them: explaining the popularity of bilateral investment treaties. Virginia Journal of International Law, v. 38, n. 639, p. 639-688, 1998. Available in: $<$ http://papers.ssrn.com/sol3/papers.cfm?abstract_id=2176003 $>$. Access: Nov. 4, 2014. 
seminados (como são hoje, com cerca de 3.000 acordos celebrados), a vantagem comparativa desapareceu - e os países encontram-se numa situação pior do que estariam se tivessem continuado cooperando.

Em suma, tem-se que a ampla disseminação dos acordos bilaterais de investimento é o resultado de uma incapacidade dos países em desenvolvimento cooperarem entre si, tendo sucumbido à tentação da deserção. Essa postura competitiva dos países em desenvolvimento os impulsiona a fornecer mais e mais proteção aos investidores internacionais ${ }^{31}$, o que os deixa em uma situação pior do que a que estariam se tivessem resistido a esses acordos coletivamente, defendendo uma regulação que fosse mais favorável aos seus interesses. Essa competição por investimento levaria a uma concessão cada vez maior de proteção aos investidores até que o benefício obtido pelos Estados do investimento se aproximaria do zero ${ }^{32}$.

Naturalmente, a existência de mecanismos de proteção do investidor não é a única - nem mesmo a principal - motivação para o investimento. Segundo Colen, Maertens e Swinnen, na prática, há apenas uma pequena contribuição dos acordos bilaterais na atração dos investimentos - sendo que os incentivos econômicos (como o tamanho do mercado, a existência de recursos naturais, a abertura ao comércio internacional, por exemplo) e as politicas internas parecem ser mais importantes na decisão do investidor ${ }^{33}$. Os autores ${ }^{34}$ citam $^{-}$

31 GUZMAN, Andrew. Why LDCs sign treaties that hurt them: explaining the popularity of bilateral investment treaties. Virginia Journal of International Law, v. 38, n. 639, p. 639-688, 1998. p. 682. Available in: <http://papers.ssrn.com/sol3/papers.cfm?abstract_ id=2176003 > . Access: Nov. 4, 2014.

32 GUZMAN, Andrew. Why LDCs sign treaties that hurt them: explaining the popularity of bilateral investment treaties. Virginia Journal of International Law, v. 38, n. 639, p. 639-688, 1998. p. 671. Available in: <http://papers.ssrn.com/sol3/papers.cfm?abstract_ $\mathrm{id}=2176003>$. Access: Nov. 4, 2014.

33 COLEN, Liesbeth; MAERTENS, Miet; SWINNEN, Johan. Determinants of foreign direct investment flows to developing countries: the role of international investment agreements. In: SCHUTTER, Olivier de; SWINNEN, Johan; WOUTERS, Jan (Ed). Foreign direct investment and buman development: the law and economics of international investment agreements. London: Routledge, 2013. p. $142-162$.

34 COLEN, Liesbeth; MAERTENS, Miet; SWINNEN, Johan. Determinants of foreign direct investment flows to developing countries: the role of international investment agreements. In: SCHUTTER, Olivier de; SWINNEN, Johan; WOUTERS, Jan (Ed). Foreign direct investment and human development: the law and economics of international investment agreements. London: Routledge, 2013. p. $142-162$. p. 152. o Brasil como indicador de que não há relação necessária entre a atração de investimento e a assinatura de APPRIs: o país figura entre os maiores receptores de investimento (o Brasil está em $5^{\circ}$ lugar no ranking dos países que mais recebem capital estrangeiro ${ }^{35}$ ), embora tenha sido resistente à assinatura de instrumentos internacionais de proteção aos investidores. No entanto, o Dilema do Prisioneiro de Guzman ajuda até mesmo a explicar a inexistência de uma correlação imediata entre o recebimento de capital e a existência dos mecanismos de proteção: a disseminação dos acordos aniquila seus efeitos enquanto vantagem comparativa aos olhos dos investidores, de tal forma que os acordos falham em seu papel de promoção de investimentos.

A perspectiva defendida por Guzman não é, contudo, aceita sem ressalvas. Ryan Bubb e Susan Rose-Ackerman ${ }^{36}$ discordam do autor: afirmam que a resistência inicial dos países em desenvolvimento ao Direito Internacional Costumeiro foi uma ação oportunista desses países - que, logo após terem conquistado sua independência, decidiram extrair o máximo de valor possível dos investimentos feitos no período colonial, cujos compromissos envolvidos não se sentiam obrigados a honrar. Após, automaticamente, passaram a respeitar os direitos de propriedade - preocupados até mesmo com sua reputação internacional caso continuassem expropriando os investidores. Os acordos internacionais de investimento, então, serviriam como um meio para um país fazer uma ruptura clara com seu comportamento no passado, fornecendo aos investidores motivos para acreditar em sua disposição renovada pela proteção de direitos de propriedade.

No mesmo sentido, defendem Eric Posner e Alan Sykes $^{37}$, para quem é possível que a resistência do mundo em desenvolvimento ao direito internacional costumeiro seja conciliável com a proposição de que os acordos bilaterais trazem benefícios aos países receptores. $\mathrm{Na}$ realidade, quando batalhavam na ONU sobre

35 UNITED NATIONS CONFERENCE ON TRADE AND DEVELOPMENT. World Investment Report 2014: investing in the SDGs: an action plan. New York: United Nations, 2014. p. 15. Available in: <http://unctad.org/en/publicationslibrary/wir2014_ en.pdf>. Access: Sept. 8, 2014.

36 BUBB, Ryan J.; ROSE-ACKERMAN, Susan. BITs and bargains: strategic aspects of bilateral and multilateral regulation of foreign investment. International Review of Law and Economics, v. 27, n. 3, p. 291-311, Sept. 2007. p. 302.

37 POSNER, Eric A.; SYKES, Alan O. economic foundations of international law. Cambridge: Harvard University, 2013. p. 283. 
as regras do Direito costumeiro, os países estavam se referindo ao direito aplicável à expropriação de investimentos já realizados - antes da assinatura de qualquer acordo internacional. Assim, os países em desenvolvimento podem ter adotado uma estratégia de explorar esses investimentos já realizados, confiando na proteção fraca do Direito costumeiro, mas podem ter percebido que as oportunidades para essa exploração diminuiria na medida em que todos os investimentos fossem expropriados ou depreciados - sendo que, nesse contexto, assinar os acordos bilaterais seria importante para garantir um renovado influxo de capital internacional dali em diante.

Ryan Bubb e Susan Rose-Ackerman ${ }^{38}$ refutam, ainda, a presunção de os acordos bilaterais de investimento deixam os países em desenvolvimento em uma posição pior do que estariam se tivessem coletivamente resistido a eles, uma vez que a disseminação dos acordos pode ser positiva aos países em desenvolvimento, desde que o fortalecimento das garantias ao investidor gere um aumento no fluxo global de capital que seja suficiente para compensar a perda na capacidade dos Estados extraírem valor dos investimentos feitos em seu território.

José Alvarez ${ }^{39}$ por sua vez, afirma que embora o primeiro acordo bilateral tenha sido firmado em 1959, os países em desenvolvimento só passaram a aceitá-los de forma entusiasmada na década de 1990, quando os esforços para modificar as regras de Direito Internacional costumeiro perante a ONU já haviam cessado. Nesse mesmo período, após a queda do Muro de Berlim, os países também começaram a adotar medidas internas liberalizantes ao capital privado, o que denota que as razões para a ratificação estão mais relacionadas a uma mudança de entendimento dos países em desenvolvimento sobre o tema do que por uma questão de detração em um Dilema do Prisioneiro propriamente dita. Além disso, muitos países se viram compelidos a assinar tais acordos não apenas para atrair mais IED, mas sim para sinalizar ao FMI a seriedade com a qual estariam comprometidos em suas exigências de ajuste estrutu-

38 BUBB, Ryan J.; ROSE-ACKERMAN, Susan. BITs and bargains: strategic aspects of bilateral and multilateral regulation of foreign investment. International Review of Law and Economics, v. 27, n. 3, p. 291-311, Sept. 2007. p. 302.

39 ALVAREZ, José E. The once and future foreign investment regime. In: ARSANJANI, Mahnoush $\mathrm{H}$. et al. (Ed.). Looking to the future: essays on international law in honor of W. Michael Reisman. Netherlands: Koninklijke Brill, 2011. p. 608-648. $\mathrm{ral}^{40}$. Outra motivação residiria nas reformas regulatórias, já que haveria uma crença de que ao assinar um APPRI, os países estariam tornando também a legislação nacional mais estável e previsível - embora Tom Ginsburg tenha realizado estudo empírico que aponta precisamente na direção contrária ${ }^{41}$.

Seja qual for a explicação correta, porém, fato é que mesmo os países desenvolvidos têm reconhecido que os acordos tornaram-se excessivamente onerosos para os países signatários, o que tem levado à uma tendência de revisão e modificação de suas cláusulas. Essa tendência também pode ser explicada com a ajuda da racionalidade econômica, mas com o complemento da filosofia de John Rawls, que trouxe uma nova luz a perspectiva do comportamento autointeressado.

\section{UMA NOVA RACIONALIDADE: AS MUDANÇAS NOS ACORDOS BILATERAIS DE INVESTIMENTO}

A falta de flexibilidade nos modelos de acordos de investimento vem sendo alvo de inúmeras críticas e esses acordos, recentemente, passaram a ser reformulados visando um maior equilíbrio em suas disposições. Um dos pioneiros nas reformas dos modelos do acordo foi os Estados Unidos, que acabou surpreendido pelos perigos do instrumento - que se tornou um aspecto preponderante de sua política externa após o governo Reagan ${ }^{42}$ - quando se viu envolvido em disputas arbi-

40 ALVAREZ, José E. The once and future foreign investment regime. In: ARSANJANI, Mahnoush $\mathrm{H}$. et al. (Ed.). Looking to the future: essays on international law in honor of W. Michael Reisman. Netherlands: Koninklijke Brill, 2011. p. 608-648.

41 Tom Ginsburg dedicou-se a analisar o impacto dos APPRIs na regulação doméstica e concluiu que, em verdade, a adoção dos acordos bilaterais de investimento piora a qualidade do Rule of Law doméstico. A explicação encontrada pelo autor é a de que a presença de alternativas internacionais às regras e cortes locais reduzem o incentivo para melhorias institucionais locais. O Poder Judiciário, por exemplo, não se sente compelido a melhorar sua qualidade temendo a concorrência da arbitragem privada - ao contrário, ele - via de regra - satisfaz-se com a diminuição da demanda. Ademais, justamente porque as instituições internacionais servem como substituto as locais, mitigando o impacto das instituições internas deficientes na atração de investimentos, o incentivo para investir em reformas institucionais é reduzido. Nesse sentido, recomenda-se a leitura de: GINSBURG, Tom. International substitutes for domestic institutions: bilateral investment treaties and governance. International Review of Law and Economics, v. 25, p. 107-123, 2005.

42 RUTTEMBERG, Valerie H. The United States bilateral investment treaty program: variations on the model. Journal of International Law, v. 9, p. 121-143, 1987. p. 121. Available in: <http://scholarship. 
trais que questionavam suas medidas domésticas. $\mathrm{O}$ acordo de investimentos celebrado no âmago do NAFTA (North American Free Trade Agreement) fez com que o País percebesse, pela primeira vez, o caráter recíproco dos compromissos firmados, já que seu sistema interno foi desafiado pelos padrões de proteção que esses acordos impunham, em especial nos casos Methanex Corp $v$. EUA, R. Loewen e Loewen Corp v. EUA e Mondev International Ltd v. EU $A^{43}$. Essa preocupação se intensificou após os trágicos acontecimentos de 11 de setembro de 2001, quando o Congresso estadunidense percebeu a possibilidade dos acordos internacionais de investimento firmados pelos Estados Unidos restringirem medidas de segurança adotadas pelo governo norte-americano em determinados setores que afetam investidores estrangeiros no país ${ }^{44}$.

Além disso, nos últimos tempos, e, em especial, após a crise econômica de 2008, as diferenças entre países exportadores e investidores de capital tornaram-se mais nebulosas, já que muitos países em desenvolvimento passaram a ser importantes exportadores de capital. Em verdade, antes da crise de 2008, os países desenvolvidos eram, ao mesmo tempo, os maiores emissores e destinatários de investimento, ao passo que os países em desenvolvimento eram quase exclusivamente receptores do capital internacional. Em 2012 - pela primeira vez na história - as economias em desenvolvimento atraíram mais investimento do que os países desenvolvidos: 52\% do capital que circulou naquele ano dirigiu-se as economias em desenvolvimento ${ }^{45}$; o mesmo ocorreu em 2013, quando 54\% do capital circulante foi destinado

law.upenn.edu $/$ cgi $/$ viewcontent. $\operatorname{cgi}$ ?article $=1639 \&$ context $=j i 1>$. Access: Nov. 15, 2014.

43 Nos três casos, medidas regulatórias internas estadunidenses foram questionadas por investidores. Ainda que não tenha saído derrotado de nenhuma disputa, os Estados Unidos perceberam, a partir delas, a possibilidade de serem questionados elos instrumentos - que até então eram vistos apenas sob a perspectiva da proteção de seus investimentos no exterior. Para mais detalhes sobre os casos, ver em: FONSECA, Karla Closs. Investimentos estrangeiros: regulamentação internacional e acordos bilaterais. Curitiba: Juruá, 2008. p. 150-154.

44 WEISS, Martin A. CRS report for congress: the US bilateral investment treaty program: an Overview. April 24, 2007. Available in: <https://www.hsdl.org/?view\&did=716235>. Access: Nov. 21, 2014.

45 UNITED NATIONS CONFERENCE ON TRADE AND DEVELOPMENT. World Investment Report 2013: global valeu chains: investment and trade for development. New York: United Nations, 2013. p. 9. Available in: <http://unctad.org/en/PublicationsLibrary/wir2013_en.pdf>. Access: Dez. 02, 2013. às economias em desenvolvimento ${ }^{46}$. As economias em desenvolvimento também aumentaram sensivelmente sua participação enquanto economias investidoras, tendo alcançado 39\% do fluxo mundial de capital em 2013 - um aumento significativo aos $12 \%$ a que correspondiam os investimentos provenientes dessas mesmas economias no início dos anos $2000^{47}$.

Além da superação parcial da dicotomia entre países investidores e países receptores de capital, há, também, uma dificuldade grande em garantir que um determinado estado será apenas investidor ou apenas receptor do investimento em razão do chamado forum shopping. Segundo Gus Van Harten e Martin Loughlin ${ }^{48}$, os acordos internacionais de investimento oferecem oportunidades abundantes para a prática do forum shopping - que consiste na possibilidade de as empresas escolherem os locais para se instalarem e se incorporarem considerando onde terão uma maior proteção jurídica. Isso significa que uma empresa pode decidir realizar um determinado investimento em um território por meio de uma subsidiária localizada no local que possua o acordo bilateral com a estrutura mais generosa de proteção - já que determinados critérios para definir a empresa como nacional sequer exigem o desempenho efetivo de atividades num país determinado, bastando para isto que nele tenha ocorrido sua incorporação.

Assim, torna-se muito mais difícil para um país ter certeza se os seus interesses em uma determinada negociação são de, exclusivamente, um país receptor ou emissor de investimentos. Isso faz com que as preocupações com esse sistema não sejam mais tão polarizadas. Não são apenas as grandes potências que abrigam empresas que investem no exterior; tampouco apenas as economias pobres e em desenvolvimento precisam

46 UNITED NATIONS CONFERENCE ON TRADE AND DEVELOPMENT. World Investment Report 2014: investing in the SDGs: an action plan. New York: United Nations, 2014. p. 9. Available in: <http://unctad.org/en/publicationslibrary/wir2014_ en.pdf >. Access: Sept. 8, 2014.

47 UNITED NATIONS CONFERENCE ON TRADE AND DEVELOPMENT. World Investment Report 2014: investing in the SDGs: an action plan. New York: United Nations, 2014. p. 9. Available in: <http://unctad.org/en/publicationslibrary/wir2014_ en.pdf>. Access: Sept. 8, 2014.

48 HARTEN, Gus Van; LOUGHLIN, Martin. Investment treaty arbitration as a species of global administrative law. The European Journal of International Law, v. 17, n. 1, p. 121-150, 2006. Available in: <http://www.uni-potsdam.de/fileadmin/projects/jur-zimmermann/LV_2010_2011/Koll_Van_HartenLoughlin_Investment_ Arbitration_as_GAL.pdf>. Access: Nov. 4, 2014. 
se preocupar com a extensão dos benefícios concedidos aos investidores internacionais. Isso faz com que a lógica da racionalidade econômica que contempla o posicionamento de países desenvolvidos e em desenvolvimento em separado precise ser revista.

A teoria de justiça de John Rawls se mostra relevante para essa análise, na medida em que promove um aperfeiçoamento na teoria da escolha racional que pode ajudar a explicar a mudança nos acordos de investimento. Em verdade, o próprio autor afirma que "a teoria de justiça é uma parte, talvez a mais importante, da teoria da escolha racional" 49 . Sua pertinência ao debate ora apresentado decorre da busca do autor pela formação de uma estrutura de cooperação que enfoca precisamente a relevância da justiça nas instituições sociais. Para o autor, "a justiça é a maior virtude das instituições sociais" $" 50$ e as teorias econômicas, leis e instituições devem ser rejeitadas quando forem injustas, já que uma injustiça só é tolerável se for o único meio para evitar uma injustiça ainda maior. Essa perspectiva alinha-se ao proposto por Guido Calabresi ${ }^{51}$, em seu enfoque à análise econômica, quando afirma que, embora seja difícil de mensurar a justiça objetivamente, ela não pode deixar de ser considerada na avaliação das normas jurídicas.

O que John Rawls ${ }^{52}$ propõe são princípios de justiça que seriam aceitos por indivíduos livres, racionais e mutuamente desinteressados, visando maximizar o seu autointeresse, em uma situação hipotética com limitações especiais que levaria a formação de uma concepção de justiça imparcial. Essa situação hipotética é chamada pelo autor de "posição original" - a qual corresponderia à situação de estado natureza, tipicamente defendida pelos teóricos contratualistas tradicionais como Hobbes, Locke e Rousseau. A posição original de Rawls, contudo, não se caracteriza como um estado histórico real ou como uma condição cultural primitiva, mas sim como um exercício hipotético ${ }^{53}$ cuja característica central é a presença do "véu da ignorância". Isto é, nas palavras de

49 RAWLS, John. A theory of justice. Cambridge: Harvard College, 1999. p. 16.

50 RAWLS, John. A theory of justice. Cambridge: Harvard College, 1999. p.3.

51 CALABRESI, Guido. The cost of accidents: a legal and economic analysis. London: Yale University, 1970. p. 35.

52 RAWLS, John. A theory of justice. Cambridge: Harvard College, 1999. p. 13.

53 RAWLS, John. A theory of justice. Cambridge: Harvard College, 1999. p. 12.
John Rawls ${ }^{54}$ :

Entre as características essenciais dessa situação é a de que ninguém conhece seu lugar na sociedade, sua classe social ou status, nem sabe nada sobre sua fortuna ou sobre a distribuição de seus bens ou aptidões, sua inteligência, sua força, e outros. Eu ainda presumo que as partes sequer sabem quais suas concepções sobre o bem e outras propensões psicológicas. Os princípios de justiça são escolhidos sob um véu da ignorância.

Ou seja, na posição original, os agentes nada sabem sobre sua posição na sociedade, de tal forma que não possuem meios para considerarem-se relevantemente diferentes dos demais e, assim, beneficiarem-se de uma eventual posição privilegiad $a^{55}$. Como ninguém está em uma posição superior de barganha, os princípios escolhidos para reger a sociedade - sob o véu da ignorância - seriam justos ${ }^{56}$.

Para John Rawls ${ }^{57}$, as partes, na posição original, elegeriam dois princípios de justiça, quais sejam: a) o princípio da igualdade - segundo o qual todos deveriam as mesmas liberdades básicas; b) o princípio da diferença que sustenta que as desigualdades econômicas e sociais só são justas quando resultam em benefícios para todos e, particularmente, para os membros menos favorecidos da sociedade. Nesse contexto, o autor defende a adoção de uma estratégia conhecida na Teoria dos Jogos que é a do maximin - ou seja, a regra do máximo mínimo ${ }^{58}$. Trata-se de uma escolha estratégica que elege, dentre os piores resultados possíveis, aquele que resulta no menor prejuízo.

Em outras palavras, por temerem estar em uma situação menos favorecida, os indivíduos, sob o véu da ignorância, decidiriam garantir que teriam um mínimo de benefícios suficientemente satisfatório. Assim, con-

54 RAWLS, John. A theory of justice. Cambridge: Harvard College, 1999. p. 12.

55 ALMEIDA, Fábio Portela Lopes. Análise jurídica da economia. Revista do Mestrado em Direito da Universidade Católica de Brasilia, Brasília, v. 1, n. 1, p. 49-101, 2007. p. 69. Disponível em: <http:// portalrevistas.ucb.br/index.php/rvmd/article/viewArticle/2617>. Acesso em: 15 dez. 2014.

56 SANDEL, Michael J. Justiça: o que é fazer a coisa certa? Tradução de Heloísa Matias e Maria Alice Máximo. 12. ed. Rio de Janeiro: Civilização Brasileira, 2013. p. 178.

57 RAWLS, John. A theory of justice. Cambridge: Harvard College, 1999. p. 14.

58 ALMEIDA, Fábio Portela Lopes. Análise jurídica da economia. Revista do Mestrado em Direito da Universidade Católica de Brasília, Brasília, v. 1, n. 1, p. 49-101, 2007. p. 69. Disponível em: <http:// portalrevistas.ucb.br/index.php/rvmd/article/viewArticle/2617>. Acesso em: 15 dez. 2014. 
cordariam que os tratamentos diferenciados só deveriam ser admitidos quando resultassem numa redução da desigualdade - e não em sua acentuação ${ }^{59}$.

Nas negociações internacionais de investimento, pensa-se que a posição original seria alcançada quando os países em negociação não soubessem se estarão na posição de investidores ou de receptores de investimentos, de tal forma que suas diferenças posicionais não afetassem a predileção por uma determinada estrutura do acordo em detrimento de outra. É por isso que José Alvarez $^{60}$ afirma que, na medida em que mais países em desenvolvimento tornam-se investidores, os países aproximam-se da posição original de Rawls - já que passam a ter interesses na proteção de suas indústrias externamente, ao passo que, os países desenvolvidos começam a preocupar-se em garantir a manutenção de um espaço regulatório tal que lhe permita adotar medidas e políticas públicas sem serem questionados em cortes internacionais quando estiverem na posição de receptores do investimento. A regra do maximin poderia ser entendida como um meio para o estabelecimento de acordos que contivessem disposições que privilegiassem os países receptores de investimento - em especial os de menor nível de desenvolvimento - suas necessidades desenvolvimentistas e os interesses de sua população.

É importante notar que o maximin de Rawls consiste em uma defesa da equidade que não deve ser confundida com as noções de igualdade que deram substrato para o pensamento comunista ou, ainda, para alguns aspectos da NOEI e dos debates sobre o Direito Internacional do Desenvolvimento na década de 1960 e 1970. A teoria do maximin não pressupõe que a distribuição dos recursos na sociedade deve ser igual - independentemente dos efeitos que esta igualdade distributiva gerará na produtividade ou na capacidade da sociedade de aumentar a soma dos bens disponíveis ${ }^{61}$. Ao contrário, a teoria expressamente autoriza a distribuição desigual de recursos que leva a um aumento no montante geral de riqueza, desde que com isso, seja possível beneficiar especialmente aqueles que estão na posição mais frágil na sociedade. Esta perspectiva autoriza que o Estado

59 FRANCK, Thomas M. Fairness in international law and institutions. New York: Oxford University, 1995. p. 18.

60 ALVAREZ, José. The public international law regime governing international investment law. Hague: The Hague Academy of International Law, 2011. p. 35.

61 FRANCK, Thomas M. Fairness in international law and institutions. New York: Oxford University, 1995. p. 19. receptor do investimento continue tendo maiores encargos do que o Estado investidor, ou mesmo do que a empresa estrangeira - desde que se verifique que tais medidas serão efetivamente compensadas por investimentos capazes de gerar resultados benéficos ao desenvolvimento da economia receptora.

Não obstante, o próprio Rawls relutou na aplicação de sua teoria no tocante ao Direito Internacional em sua obra "O Direito dos Povos" 62 . Em verdade, o Princípio da Diferença (maximin) está ausente de sua concepção de justiça para a sociedade internacional, já que o autor entende que a intervenção internacional deve servir apenas para auxiliar os países a criarem instituições liberais - já que os infortúnios de alguns países decorreriam exclusivamente de sua má organização política (e não de uma escassez de recursos ${ }^{63}$. Além disso, o autor coloca em dúvida a obrigação moral dos países mais ricos com os mais pobres na seara internacional - onde não haveria uma comunidade global ${ }^{64}$.

Joffrey Dunoff e Joel Trachtman ${ }^{65}$ concordaram com essa perspectiva, ao aplicar os pressupostos da escolha racional ao Direito Internacional, defendendo que o Direito Internacional não funciona como os sistemas domésticos, nos quais é comum que os indivíduos se disponham a conceder autoridade para decisões alocativas institucionais que visem uma distribuição de recursos. Na sociedade internacional, essa solidariedade é - segundo os autores - menos firme: há uma sensação menor de valores compartilhados, uma menor disposição para aceitar os custos de decisões que geram prejuízos no curto prazo pelo benefício de uma vida em sociedade - o que faria com que os Estados tivessem uma menor predisposição para a celebração de acordos sob a ótica do "véu da ignorância".

Não obstante, a integração global constante tem elevado o sentimento de solidariedade da esfera internacional. É o que sustenta Thomas Franck ${ }^{66}$, para quem

62 RAWLS, John. O direito dos povos. Tradução de Luís Carlos Borges. São Paulo: M. Fontes, 2001.

63 RAWLS, John. O direito dos povos. Tradução de Luís Carlos Borges. São Paulo: M. Fontes, 2001. p. 142.

64 RAWLS, John. O direito dos povos. Tradução de Luís Carlos Borges. São Paulo: M. Fontes, 2001. p. 119.

65 DUNOFF, Joffrey L.; TRACHTMAN, Joel P. Economic analysis of international law: an invitation and a caveat. April 20, 1998. p. 37. Available in: <http://papers.ssrn.com/sol3/papers.cfm?abstract_ $\mathrm{id}=73688>$. Access: Out. 22, 2014.

66 FRANCK, Thomas M. Fairness in international law and institutions. New York: Oxford University, 1995. p. 5. 
há um sentimento crescente de comunidade global que tornaria perfeitamente justificável a aplicação do maximin nas alocações de recursos internacionais. Para o autor, desde a chegada do homem ao espaço, quando se percebeu a pequenez da Terra como o único habitat possível a todos os homens diante da imensidão do universo, a autopercepção das pessoas ao redor do mundo quanto a suas interconexões enquanto humanidade - um conjunto de seres humanos com anseios, aspirações e necessidades semelhantes e interligadas - tem crescido $^{67}$. Dentro desse contexto, é possível acatar os postulados da racionalidade - reconhecendo que os Estados seguirão o Direito Internacional quando os benefícios de fazê-lo excederem os custos - mas admitindo que escolha racional não precisa decorrer de cálculo de custo-benefício egoístico acerca de regras particulares, mas sim em uma análise mais ampla e profunda, baseada no impulso de solidariedade e cooperação que move as nações ao se sentirem todas como membros de um mesmo clube ${ }^{68}$.

De fato, diversas questões inter-relacionam e conectam as pessoas dos mais diferentes lugares do mundo atualmente. As diferenças econômicas e de padrões de vida entre os países - que sempre existiram - tornaram-se menos suportáveis com o advento das comunicações instantâneas e as reinvindicações por igualdade alcançam escala global ${ }^{69}$. Além disso, problemas sem fronteiras - como a crise ambiental e o terrorismo, por exemplo - suscitam a percepção do planeta como um todo conectado e interligado na busca por um futuro comum. Pensa-se, assim, que as condições para a aplicação do maximin na esfera internacional - se já não existem - estão cada vez mais próximas. Em verdade, o critério de Rawls tem sido utilizado em relatórios da ONU para reforçar a opinião de que, na cooperação internacional pelo desenvolvimento, deve ser dada prioridade àqueles em situação marginalizada, de forma a favorecer os grupos mais vulneráveis da sociedade ${ }^{70}$.

67 FRANCK, Thomas M. Fairness in international law and institutions. New York: Oxford University, 1995. p. 5.

$68 \mathrm{KOH}$, Harold Hongiu. Why do nations obey international law? Yale law school faculty scholarship. p. 2062. Available in: <http://digitalcommins.law.yale.edu/fss_papers/2101>. Access: Dez. 31, 2014. 69 MELLO, Celso Albuquerque de. Direito internacional econômico. Rio de Janeiro: Renovar, 1993. p. 12.

70 OLIVEIRA, Silvia Menicucci. Financiamento internacional do desenvolvimento: seu papel na implementação do direito ao desenvolvimento. In: AMARAL JUNIOR, Alberto. Direito internacional e desenvolvimento. Barueri: Manole, 2005. p. 219-252. p. 223.
Nessa perspectiva, acredita-se que as conexões entre os países hoje e o "véu da ignorância" que recai sobre negociadores na celebração de acordos de investimento em que a posição das partes não é mais tão definida torna possível uma busca por acordos que tenham como objetivo concretizar globalmente o desenvolvimento econômico sustentável e harmônico entre os Estados, pois esta pode ser, além de uma questão ética e moral, também uma questão necessária à busca pelo melhor interesse dos países individualmente - inclusive os mais desenvolvidos.

A tendência de reforma nos acordos de investimento aponta nessa direção. O modelo elaborado pela Noruega, por exemplo, concatena ideais desenvolvimentistas com a necessidade de proteção dos investidores internacionais ${ }^{71}$. $\mathrm{O}$ mesmo pode ser dito do modelo brasileiro: os acordos assinados recentemente diferem do modelo da década de 1990 até no nome. Os tradicionais "Acordos de Promoção e Proteção de Investimentos" encontram-se agora sob a roupagem de "Acordo de Cooperação e Facilitação de Investimentos", e suas previsões são substancialmente diferentes em diversos aspectos.

Pautado no diálogo intergovernamental, o acordo cria obrigações tanto para Estados receptores do investimento (por meio das garantias de proteção) quanto para o Estado de origem do investidor (que devem participar ativamente de debates e do compartilhamento de oportunidades para expansão dos investimentos, trocar informações e participar de agendas temáticas para facilitação de investimentos recíprocos) ${ }^{72}$. Além disso, o acordo também inova por estabelecer obrigações de responsabilidade social corporativa aos investidores, que devem comprometer-se com o respeito aos direitos humanos, manter políticas de governança corporativa e absterem-se de práticas nocivas à economia receptora ${ }^{73}$.

71 73KINGDOM OF NORWAY. Agreement between the Kingdom of Norway and for the promotion and protection of investments. Available in: <http://www.italaw.com/sites/default/files/archive/ita1031.pdf > Access: Nov. 15, 2014.

72 BRASIL. Ministério das Relações Exteriores. Acordo BrasilMoçambique de Cooperação e Facilitacãa de Investimentos (ACFI): Maputo, 30 de março de 2015. Brasília: MRE, 30 mar. 2015. Disponível em: $<$ www.itamaraty.gov.br/index.php?option $=$ com_content\&view $=$ ar ticle $\&$ id $=8511 \&$ catid $=42 \&$ Itemid $=280 \&$ lang $=p t-B R>$. Acesso em: 2 set. 2015

73 MONEBHURRUN, Nitish. Crônicas do direito internacional dos investimentos. Revista de Direito Internacional, Brasília, v. 12, n. 1, p. 32-36, 2015. p. 32-36. 
A decisão brasileira de celebrar acordos de investimento nesse momento, mesmo depois de ter expressamente refutado os acordos assinados na década de 1990, advém da nova posição do país nesses embates: é cada vez mais comum que empresas brasileiras invistam no exterior ${ }^{74}$. É de se destacar, em relação a esse contexto que algumas empresas brasileiras já foram impactadas por medidas hostis adotadas por governos vizinhos. Em 2006, o presidente boliviano Evo Morales anunciou a expropriação de investimentos estrangeiros no setor de petróleo e gás natural de seu país, incluindo, dentre as empresas expropriadas, uma subsidiária holandesa da Petrobrás. Além disto, em 2008, a empresa Odebrecht e a FURNAS foram expulsas do Equador pelo presidente Rafael Correa, em razão de problemas encontrados pelo governo na hidrelétrica São Francisco ${ }^{75}$. A proteção dos investidores nacionais torna-se, assim, uma preocupação a ser considerada pelo governo brasileiro.

Porém, ao contrário do que se poderia supor, o Brasil não está negociando apenas com países nos quais o fluxo de investimentos é unilateral. Apesar dos acordos assinados com países africanos representarem uma resposta à demanda de grandes empresas - em especial construtoras - brasileiras que participam de grandiosos projetos no continente, o Brasil assinou acordo também com o México, mesmo sendo o principal destino de investimentos mexicanos na América Latina ${ }^{76}$. Da mesma forma, o fluxo de investimentos entre o Brasil e Chile é recíproco ${ }^{77}$. Assim, pode-se dizer que o Brasil encontra-se coberto pelo "véu da ignorância" nessas situações,

74 O estoque de investimentos do Brasil no exterior subiu de \$42bilhões em 2001 para U\$266,3 bilhões em 2013. Nesse sentido, ver em: BANCO CENTRAL DO BRASIL. Capitais brasileiros no exterior: ano base 2012. Disponível em: <http://www4.bcb.gov.br/rex/ CBE/Port/ResultadoCBE2012p.pdf>. Acesso em: 04 dez. 2013.

75 MACHADO, Artur Andrade da Silva. O caso Odebrecht e o dilema da liderança regional brasileira. Meridiano 47. Disponível em: <http://periodicos.unb.br/index.php/MED/article/ view/851/519>. Acesso em: 17 nov. 2015.

76 BRASIL. Ministério das Relações Exteriores. Acordo BrasilMéxico de Cooperação e Facilitação de Investimentos: Cidade do México, 26 de maio de 2015. Brasília: MRE, 27 maio 2015 Disponível em: $<$ http://www.itamaraty.gov.br/index.php?option=com_conten $\mathrm{t} \&$ view $=$ article $\& i d=9890$ :acordo-brasil - mexico-de-cooperacaoe-facilitacao-de-investimentos-cidade-do-mexico-26-de-maio-de$2015 \&$ catid $=42 \&$ lang $=$ pt $-B R \&$ Itemid $=280>$. Acesso em: 03 fev. 2016.

77 BRASIL. Ministério do Desenvolvimento, Indústria e Comércio Exterior. Brasil e Chile assinam acordo de cooperação e facilitação de investimentos. Brasil: MDIC, nov. 2015. Disponível em: <http://www. mdic.gov.br/sitio/interna/noticia.php?area $=5 \&$ noticia $=14186>$. Acesso em: 07 dez. 2015. pois precisou pensar em um acordo que englobasse suas demandas tanto como país receptor de investimentos quanto como investidor.

O que se nota, portanto, é que os acordos de investimento não devem ser abolidos. Ao contrário, os acordos são uma solução cooperativa entre Estados receptores e investidores para um problema real: a falta de confiabilidade dos investidores nas instituições domésticas dos países em que investem - o que acaba por desestimular o ingresso de capital especialmente necessário aos países mais pobres, que também são os que despertam maiores desconfianças quanto à qualidade de seus sistemas institucionais. Contudo, uma vez que se reconhecem os benefícios da cooperação, é preciso reconhecer que esta não se restringe a um modelo único. Em verdade, "quando a cooperação produz ganhos, muitos arranjos são possíveis"

Pautando-se nos pressupostos de maximin defendidos por Rawls, pode-se pensar em acordos de investimento calibrados com diferentes níveis de obrigações conforme o nível de desenvolvimento do país signatário - de modo semelhante às disposições do GATT que atribuem responsabilidades diferenciadas para os países menos desenvolvidos ${ }^{79}$. Pode ser desejável incluir, como fez o modelo brasileiro, obrigações para as empresas investidoras entre as disposições dos acordos, modificando seu o caráter unilateral que, até então, estabelece apenas deveres para os Estados receptores do investimento. Dar continuidade às iniciativas de revisão das cláusulas abertas, como a do tratamento justo e equitativo e da expropriação indireta, evitando que continuem

78 SEN, Amartya; KLIKSBERG, Bernardo. As pessoas em primeiro lugar: a ética no desenvolvimento e os problemas do mundo globalizado. Tradução de Bernardo Ajzemberg e Calos Eduardo Lins da Silva. São Paulo: Companhia das Letras, 2010. p. 19.

79 Há, no GATT, um total de 25 previsões diferenciadas para países em desenvolvimento, contidas nos artigos XVIII, XXXVI, XXXVII e XXXVIII. Tais medidas incluem o estabelecimento de oportunidades para aumentar o comércio nos países em desenvolvimento (artigos XXXVI.2, XXXVI.3, XXXVI.4, XXXVI.5, XXXVII.1(a), XXXVII.4, XXXVIII.2(c),(e); medidas de flexibilidade quanto aos compromissos, ações e uso dos instrumentos (artigos XXXVI.8, XVIII,7(a), XVIII.8 e XVIII.13) e previsões acerca da salvaguarda dos interesses de países em desenvolvimento (artigos XXXVI.5, XXXVI.7, XXXVI.9, XXXVII.1(b),(c), XXXVII.2, XXXVII.3, XXXVII.5, XXXVIII.1, XXXVIII.2(a), (b), (d), (f)). Nesse sentido, ver em: WTO. Special and differential treatment provisions. WORLD TRADE ORGANIZATION. Special and differential treatment provisions. Geneve: WTO, 2015. Available in: $<$ https://www.wto.org/english/tratop_e/devel_e/dev_special_differential_provisions_e.htm >. Access: Nov. 12, 2015. 
sendo percebidas como uma caixa-preta de onde podem emergir indesejadas surpresas para os países signatários ${ }^{80}$, é também importante.

Uma mudança nos acordos de investimento é desejável e possível, não apenas por um desejo de uma sociedade internacional mais justa e equilibrada, mas também porque esse caminho é o mais indicado a ser tomado pelos Estados, concebidos como agentes econômicos racionais que desconhecem sua posição nas negociações de investimento. A partir do momento que os agentes em negociação percebem que sua racionalidade posicional pode ser variável - ora podendo ser um Estado investidor desejoso da proteção de seus empresários nacionais, ora um receptor do investimento, necessitando manter um espaço razoável para o "direito de regular" - um novo horizonte se abre para esses acordos, que devem se tornar cada vez mais equilibrados e menos intrusivos.

\section{Considerações finais}

O presente artigo permitiu concluir que a decisão dos países de participar de acordos bilaterais de investimento pode ser mensurada com base no pressuposto da racionalidade econômica. Em outras palavras, os países devem se engajar nas negociações desses acordos quando perceberem que estão em uma melhor situação em fazê-lo do que estariam sem esse instrumento de regulação internacional.

Essa análise pode ser útil para ponderar sobre a mudança de perspectiva brasileira quanto ao tema: apesar de ter assinado 14 acordos na década de 1990, o país optou por não ratificá-los em 2002. Hoje, porém, negocia acordos pautados em uma lógica distinta, mais equilibrados às necessidades dos países receptores e emissores de investimento do que os acordos tradicionais. Nota-se, assim, que, se em 2002, com a análise de custo-benefício realizada pelo governo brasileiro concluiu-se por uma desnecessidade desses instrumentos, há uma série de fatos novos a serem considerados atualmente e é preciso rediscutir o assunto.

80 WALLACE, Perry. International investment law and arbitration, sustainable development, and Rio+20: improving corporate institutional and state governance. Sustainable Development Law and Policy, v. 12, n. 3, p. 22-28; 55-56, 2012. p. 23. Available in: $\quad<$ http://digitalcommons.wcl.american.edu/cgi/viewcontent. coi $P$ article $=1535 \&$ context $=$ sdlp $>$. Access: Jan. 29, 2015.
Em um primeiro momento, um novo cenário para os acordos está se formando e, paulatinamente, as grandes potências têm dado abertura para rediscutir os acordos de investimento, reformando seus modelos para incluir disposições mais equilibradas, com maiores considerações aos interesses dos Estados receptores. Além disso, a visão de que os acordos são irrelevantes para o Brasil tomando-o por um país exclusivamente receptor de capital e com fatores de atração relevantes (tais como um grande mercado doméstico e uma legislação liberal para regular nacionalmente o investimento estrangeiro, o que justifica o recebimento de grande influxo de capital a despeito do não fornecimento das garantias internacionais de proteção) - não se sustenta diante da percepção de que o país se torna, cada vez mais, uma economia exportadora de capital.

Dentro desse contexto, entende-se que o país não pode mais manter-se alheio ao papel importante dos acordos de investimento na proteção das empresas nacionais contra riscos políticos e institucionais nos países em que investem. Essa maior proteção, porém, não necessariamente precisa ser pautada sob uma lógica egocêntrica do país investidor, mas sim com a devida atenção às necessidades também da economia receptora, posto que o Brasil está em uma posição em que compreende e possui interesses nos dois lados do jogo. Em muitos casos, pode-se dizer que o Brasil é, verdadeiramente, um agente coberto pelo "véu da ignorância" na posição original pensada por Rawls - em condições, portanto, de elaborar acordos alinhados com as ideias de justiça ponderadas pelo autor e pautados na lógica do maximin.

Com seu novo modelo, pensa-se que o país poderia assumir a liderança de um processo de reforma do Direito Internacional dos Investimentos Estrangeiros, atuando de modo preocupado em garantir um sistema eficiente e equilibrado de proteção dos investidores que seja também solidário às necessidades desenvolvimentistas das economias receptoras. O país está numa posição privilegiada para isso justamente porque não se comprometeu com os acordos formulados sob a lógica do Consenso de Washington na década de 1990, estando livre para estabelecer um modelo novo sem amarras com compromissos internacionais anteriormente firmados. Além disto, seu poder de barganha é considerável nos debates sobre investimento: justamente por ter fatores atrativos em sua economia que lhe permitem atrair capital mesmo na ausência de um acordo, o 
país pode usar da ameaça de abandonar as negociações quando elas não estiverem caminhando na direção de seus interesses - o que não ocorre com as economias que apostam nos acordos internacionais de investimento como meios para criarem fatores de atração às suas economias.

Assim, a postura brasileira pode servir para dar força ao processo de reforma nos acordos globais, pautando-se numa perspectiva ampliada de desenvolvimento e atuando de modo solidário aos interesses dos países mais pobres. Trata-se, ao mesmo tempo, um imperativo moral e também uma estratégia que pode servir ao Brasil sob uma perspectiva de maximização racional: fazer parte de um acordo equilibrado traria mais benefício aos seus investidores locais do que manter-se distante dessa estrutura de proteção; por outro lado, na condição de receptor de capitais, o Brasil precisa assegurar um devido espaço para a elaboração de políticas públicas de desenvolvimento nacionais e para medidas de regulação movidas por interesses públicos, razão pela qual não deve concordar com propostas de acordo que repetem a lógica altamente intrusiva dos acordos bilaterais tradicionais.

É de se destacar, também, a importância da regulação internacional dos investimentos estrangeiros em um cenário de intensificação da criação de normas positivas em âmbito internacional, uma vez que a existência desses acordos serve para trazer clareza e segurança jurídica para relações econômicas cada vez mais frequentes no cenário global.

O que se nota, portanto, no cenário atual das negociações de investimento é que existe uma janela de oportunidade para que a adesão à regulação internacional dos investimentos estrangeiros possa ser repensada pelas autoridades brasileiras. Percebe-se que o Brasil já está caminhando nessa direção com seu novo modelo de acordo. É uma mudança de perspectiva importante e, muito embora, os acordos ainda estejam pendentes de ratificação e sua eficácia e impactos ainda precisem ser mensurados, a mera celebração desses novos modelos é um marco não só na política externa brasileira, mas para todo o Direito Internacional dos Investimentos Estrangeiros.

\section{REFERÊNCIAS} economia. Revista do Mestrado em Direito da Universidade Católica de Brasília, Brasília, v. 1, n. 1, p. 49-101, 2007. Disponível em: <http://portalrevistas.ucb.br/index. $\mathrm{php} / \mathrm{rvmd} /$ article/viewArticle/2617>. Acesso em: 15 dez. 2014.

ALVAREZ, José E. The once and future foreign investment regime. In: ARSANJANI, Mahnoush H. et al. (Ed.). Looking to the future: essays on international law in honor of W. Michael Reisman. Netherlands: Koninklijke Brill, 2011. p. 608-648.

ALVAREZ, José. The public international law regime governing international investment law. Hague: The Hague Academy of International Law, 2011.

ARENHART, Fernando Santos. Investimento estrangeiro: o padrão de tratamento justo e equitativo e o papel da boa fé. Revista de Direito Internacional, Brasília, v. 10, n. 1, p. 154-169, 2013.

AXELROD, Robert. A evolução da cooperação. São Paulo: Leopardo, 2010.

BANCO CENTRAL DO BRASIL. Capitais brasileiros no exterior: ano base 2012. Disponível em: <http://www4. bcb.gov.br/rex/CBE/Port/ResultadoCBE2012p.pdf >. Acesso em: 04 dez. 2013.

BRASIL. Ministério das Relações Exteriores. Acordo Brasil-México de Cooperação e Facilitação de Investimentos: Cidade do México, 26 de maio de 2015. Brasília: MRE, 27 maio 2015 Disponível em: <http://www.itamaraty. gov.br $/$ index.php?option $=$ com_content\&view $=$ artic le\&id =9890:acordo-brasil-mexico-de-cooperacao-efacilitacao-de-investimentos-cidade-do-mexico-26-demaio-de-2015\&catid $=42 \&$ lang $=$ pt-BR\&Itemid $=280>$. Acesso em: 03 fev. 2016.

BRASIL. Ministério das Relações Exteriores. Acordo Brasil-Moçambique de Cooperação e Facilitação de Investimentos (ACFI): Maputo, 30 de março de 2015. Brasília: MRE, 30 mar. 2015. Disponível em: <www.itamaraty.gov.br/ index.php?option $=$ com_content\&view $=$ article\&id $=85$ $11 \&$ catid $=42 \&$ Itemid $=280 \&$ lang $=p t-B R>$. Acesso em: 2 set. 2015.

BRASIL. Ministério do Desenvolvimento, Indústria e Comércio Exterior. Brasil e Chile assinam acordo de cooperação e facilitação de investimentos. Brasil: MDIC, nov. 2015. Disponível em: <http://www.mdic.gov.br/sitio/inter$\mathrm{na} /$ noticia.php?area $=5 \&$ noticia $=14186>$. Acesso em: 
07 dez. 2015.

BUBB, Ryan J.; ROSE-ACKERMAN, Susan. BITs and bargains: strategic aspects of bilateral and multilateral regulation of foreign investment. International Review of Law and Economics, v. 27, n. 3, p. 291-311, Sept. 2007.

CALABRESI, Guido. The cost of accidents: a legal and economic analysis. London: Yale University, 1970.

COLEN, Liesbeth; MAERTENS, Miet; SWINNEN, Johan. Determinants of foreign direct investment flows to developing countries: the role of international investment agreements. In: SCHUTTER, Olivier de; SWINNEN, Johan; WOUTERS, Jan (Ed). Foreign direct investment and human development: the law and economics of international investment agreements. London: Routledge, 2013. p. 142-162.

COSTA, José Augusto Fontoura. Direito internacional do investimento estrangeiro. Curitiba: Juruá, 2010.

COSTA, José Augusto Fontoura. Modelos de Solução de Controvérsias Investidor-Estado: os mecanismos nacionais e internacionais. In: AMARAL JÚNIOR, Alberto do; SANCHEZ, Michelle Ratton. Regulamentação internacional dos investimentos: algumas lições para o Brasil. São Paulo: Aduaneiras, 2007. p. 325-354.

CUNNINGHAM, S. M. Multinationals and restructuring in Latin America. In: DIXON, Chris; DRAKAKIS-SMITH, David; WATTS, Doug (Ed.). Multinational corporations and the third world. New York: Routledge, 1986. v. 11. p. 39-65.

DIAS, Bernadete de Figueiredo. A abordagem do direito ao desenvolvimento nos tratados sobre investimentos. In: AMARAL JÚNIOR, Alberto do (Org.). Direito internacional e desenvolvimento. Barueri: Manole, 2005. p. 253-269.

DOLZER, Rudolf; SCHREUER, Christoph. Principles of international investment law. Oxford: Oxford University, 2012.

DUNOFF, Joffrey L.; TRACHTMAN, Joel P. Economic analysis of international law: an invitation and a caveat. April 20, 1998. Available in: <http://papers.ssrn.com/ sol3 $/$ papers.cfm?abstract_id $=73688>$. Access: Out. 22, 2014.

FONSECA, Karla Closs. Investimentos estrangeiros: regulamentação internacional e acordos bilaterais. Curitiba: Juruá, 2008.
FRANCK, Thomas M. Fairness in international law and institutions. New York: Oxford University, 1995.

GERMANY. Treaty between the Federal Republic of Germany and Pakistan for the prootion and protection of investments. Available in: <http://investmentpolicyhub.unctad.org/ Download/TreatyFile/1387>. Access: Out. 29, 2014.

GICO JR., Ivo. Metodologia e epistemologia da análise econômica do direito. Economic Analysis of Law Review, v. 1, n. 1, p. 7-33, Jan./June 2010. Available in: <http:// portalrevistas.ucb.br/index.php/EALR/article/ view/1460/1110>. Access: Out. 21, 2014.

GINSBURG, Tom. International substitutes for domestic institutions: bilateral investment treaties and governance. International Review of Law and Economics, v. 25, p. 107-123, 2005.

GUZMAN, Andrew. Why LDCs sign treaties that hurt them: explaining the popularity of bilateral investment treaties. Virginia Journal of International Law, v. 38, n. 639, p. 639-688, 1998. Available in: <http://papers.ssrn. com $/$ sol3 $/$ papers.cfm?abstract_id $=2176003>$. Access: Nov. 4, 2014.

HARTEN, Gus Van. Investment treaty arbitration and public law. Oxford: Oxford University, 2007.

HARTEN, Gus Van; LOUGHLIN, Martin. Investment treaty arbitration as a species of global administrative law. The European Journal of International Law, v. 17, n. 1, p. 121-150, 2006. Available in: <http://www.unipotsdam.de/fileadmin/projects/jur-zimmermann/ LV_2010_2011/Koll_Van_HartenLoughlin_Investment_Arbitration_as_GAL.pdf>. Access: Nov. 4, 2014.

INTERNATIONAL CENTRE FOR SETTLEMENT OF INVESTMENT DISPUTES. The ICSID Caseload: Statistics (Issue 2014-2). Washigton: ICSID, 2014. Available in: <https://icsid.worldbank.org/apps/ICSIDWEB/resources/Documents/ICSID $\% 20 W$ Web $\% 20$ Stats $\% 202014-2 \% 20$ (English).pdf $>$. Access: Nov. 23, 2014.

KINGDOM OF NORWAY. Agreement between the Kingdom of Norway and for the promotion and protection of investments. Available in: <http://www.italaw.com/sites/ default/files/archive/ita1031.pdf>. Access: Nov. 15, 2014.

$\mathrm{KOH}$, Harold Hongiu. Why do nations obey international law? Yale law school faculty scholarship. Availa- 
ble in: <http://digitalcommins.law.yale.edu/fss_papers/2101>. Access: Dez. 31, 2014.

KULICK, Andreas. Global public interest in international investment law. Cambridge: Cambridge University, 2012.

MACHADO, Artur Andrade da Silva. O caso Odebrecht e o dilema da liderança regional brasileira. $\mathrm{Me}$ ridiano 47. Disponível em: <http://periodicos.unb.br/ index.php/MED/article/view/851/519>. Acesso em: 17 nov. 2015.

MELLO, Celso Albuquerque de. Direito internacional econômico. Rio de Janeiro: Renovar, 1993.

MILES, Kate. The origins of international investment law. Cambridge: Cambridge University, 2013.

MONEBHURRUN, Nitish. Crônicas do direito internacional dos investimentos. Revista de Direito Internacional, Brasília, v. 11, n. 1, p. 10-18, 2014.

MONEBHURRUN, Nitish. crônicas do direito internacional dos investimentos. Revista de Direito Internacional, Brasília, v. 12, n. 1, p. 32-36, 2015.

MONEBHURRUN, Nitish. Essay on unequal treaties and modernity throgh the example of bilateral investment treaties. Revista de Direito Internacional, Brasilia, v. 11, n. 1, p. 202-214, 2014.

NORTH, Douglass C. Economic performance through time. American Economic Review, v. 84, n. 3, p. 359-368, June 1994.

OLIVEIRA, Silvia Menicucci. Financiamento internacional do desenvolvimento: seu papel na implementação do direito ao desenvolvimento. In: AMARAL JUNIOR, Alberto. Direito internacional e desenvolvimento. Barueri: Manole, 2005. p. 219-252.

OLSON, Mancur. The logic of collective action: public goods and the theory of groups. Cambridge: Harvard University, 1965.

PINHEIRO FILHO, Francisco Renato Codevila. Teoria da agência: problema agente-principal. In: RIBEIRO, Márcia Carla Pereira; KLEIN, Vinícius (Coord.). O que é análise econômica do direito: uma introdução. Belo Horizonte: Fórum, 2011. v. 1. p. 97-109.

POSNER, Eric A.; SYKES, Alan O. Economic foundations of international law. Cambridge: Harvard University, 2013.

POSTIGA, Andréa Rocha. A emergência do direito administrativo global como ferramenta de regulação transnacional do investimento estrangeiro direto. Revista de Direito Internacional. Brasília, v. 10, n. 1, p. 171-193, 2013.

RAWLS, John. A theory of justice. Cambridge: Harvard College, 1999.

RAWLS, John. O direito dos povos. Tradução de Luís Carlos Borges. São Paulo: M. Fontes, 2001.

RUT'TEMBERG, Valerie H. The United States bilateral investment treaty program: variations on the model. Journal of International Law, v. 9, p. 121-143, 1987. Available in: <http://scholarship.law.upenn.edu/cgi/ viewcontent.cgi?article $=1639 \&$ context $=$ jil $>$. Access: Nov. 15, 2014.

SANDEL, Michael J. Justiça: o que é fazer a coisa certa? Tradução de Heloísa Matias e Maria Alice Máximo. 12. ed. Rio de Janeiro: Civilização Brasileira, 2013.

SCANDIUCCI FILHO, José Gilberto. O Brasil e os acordos bilaterais de investimentos. In: AMARAL JÚNIOR, Alberto do; SANCHEZ, Michelle Ratton. Regulamentação internacional dos investimentos: algumas lições para o Brasil. São Paulo: Aduaneiras, 2007. p. 271-302.

SCHILL, Stephan W. The mutilateralization of international investment law. Cambridge: Cambridge University, 2009.

SCOTT, Robert E.; STEPHAN, Paul B. The limits of Leviathan: contract theory and the enforcement of international law. Cambridge: Cambridge University, 2006.

SEN, Amartya; KLIKSBERG, Bernardo. As pessoas em primeiro lugar: a ética no desenvolvimento e os problemas do mundo globalizado. Tradução de Bernardo Ajzemberg e Calos Eduardo Lins da Silva. São Paulo: Companhia das Letras, 2010.

SEN, Amartya. A ideia de justiça. Tradução de Denise Bottmann e Ricardo Doninelli Mendes. São Paulo: Companhia das Letras, 2009.

SORNARAJAH, M. The international Law on Foreign Investment. Cambridge: Cambridge University, 2010.

STIGLITZ, Joseph E. Globalização: como dar certo. São Paulo: Companhia das Letras, 2007.

TAYLOR, Matthew. Philip Morris v Australia: the challenges of investor-state arbitration. Available in: $<$ http://www.mallesons.com/publications/marketAlerts/2011/International-Arbitration-Update-November-2011/Pages/Philip-Morris-v-Australia-the-challen- 
ges-of-investor-state-arbitration.aspx>. Access: Aug. 26, 2014.

UNITED NATIONS CONFERENCE ON TRADE AND DEVELOPMENT. World Investment Report 2013: global valeu chains: investment and trade for development. New York: United Nations, 2013. Available in: <http://unctad.org/en/PublicationsLibrary/ wir2013_en.pdf>. Access: Dez. 02, 2013.

UNITED NATIONS CONFERENCE ON TRADE AND DEVELOPMENT. World Investment Report 2014: investing in the SDGs: an action plan. New York: United Nations, 2014. Available in: <http://unctad.org/ en/publicationslibrary/wir2014_en.pdf>. Access: Sept. 8, 2014.

WALLACE, Perry. International investment law and arbitration, sustainable development, and Rio +20 : improving corporate institutional and state governance. Sustainable Development Law and Policy, v. 12, n. 3, p. 22-28; 55-56, 2012. Available in: <http://digitalcommons.wcl.american.edu/cgi/viewcontent. cgi?article $=1535 \&$ context $=$ sdlp $>$. Access: Jan. 29, 2015.

WEISS, Martin A. CRS report for congress: the US bilateral investment treaty program: an overview. April 24, 2007. Available in: <https://www.hsdl. org/?view\&did=716235>. Access: Nov. 21, 2014.

WOUTERS, Jan; DUQUET, Sanderijn; HACHEZ, Nicolas. International investment law: the perpetual search for consensus. In: SCHUTTER, Olivier de; SWINNEN, Johan; WOUTERS, Jan. Foreign direct investment and human development: the law and economics of international investment agreements. London: Routledge, 2013. p. 25-69. 
Para publicar na Revista de Direito Internacional, acesse o endereço eletrônico www.rdi.uniceub.br ou www.brazilianjournal.org.

Observe as normas de publicação, para facilitar e agilizar o trabalho de edição. 